\title{
The WW II German Coastal Artillery Battery H.K.B.1274/StP C342 at Camaret sur Mer (Finistère-FR)
}

\author{
Giancarlo T. Tomezzoli \\ Etno-Archaeological Observatory, Munich, Germany \\ Email: gt21949@gmx.de
}

How to cite this paper: Tomezzoli, G. T. (2017). The WW II German Coastal Artillery Battery H.K.B.1274/StP C342 at Camaret sur Mer (Finistère-FR). Archaeological Discovery, 5, 116-141. https://doi.org/10.4236/ad.2017.53008

Received: May 2, 2017

Accepted: July 5, 2017

Published: July 11, 2017

Copyright $\odot 2017$ by author and Scientific Research Publishing Inc. This work is licensed under the Creative Commons Attribution International License (CC BY 4.0).

http://creativecommons.org/licenses/by/4.0/

\begin{abstract}
In previous articles dedicated to various German military structures of the Atlantic Wall in West Brittany, the preservation state and the organization of their components have been analyzed. The components have generally been found in a good preservation state without damages due to combats or bombardments. This is not the case of the components of the German coastal artillery battery HKB1274/StP C342 described in this article. The article shows also the organization of the battery, how it integrated pre-existing French military structures and how a massive allied air bombardment affected it.
\end{abstract}

\section{Keywords}

H.K.B.1274, StP C342, German, Coastal, Battery, Atlantic Wall, Finistère, Goulet, Brest, France

\section{Introduction}

The necessity to defend the sea entrance or Goulet to the port of Brest (France) against enemy intrusions already emerged during the last French Religion War, on Mars 1594, when Spanish troops occupied the peninsula of Roscanvel, on the south side of the Goulet, and erected a fort for cutting sea supplies to Brest under siege. It was necessary for the French, a harsh siege one month long, up to November 1594, to defeat the Spanish garrison barricaded in the fort. The necessity emerged much more strongly from 1631, year in which the first minister of King Louis XIII cardinal Richelieu decided to create an important base for the French Royal Fleet in Brest. The Goulet was then defended by artillery batteries constructed along its coasts in the period 1670-1680 under the direction of the minister of the Fleet Colbert.

The marshal of France Vauban, under King Louis XIV, disposed the construc- 
tion of strongholds along the Goulet coasts which in case of attack could be supported by regular troups stationed in the interior lands. Because the gulf of Camaret sur Mer, on the south side of the Goulet, represented an ideal place for foreign troupes landing, he disposed the construction of a fortress in the port of Camaret, just in time, during the French-Spanish war, on $18^{\text {th }}$ June 1694, for rejecting the landing of a British-Dutch invasion force on the nearby Trez-Rouz beach, named after that "British Death".

The Goulet, near Camaret, was objet of further defensive constructions, consisting on the Petit Gouin pointe: on 1813 an artillery battery, on 1859 a crenelated guardhouse of $2^{\text {nd }}$ type, mod. 1846 (40 soldiers and 8 guns) as part of a 1846 - 1862 protection program of the French coasts and, at the end of $19^{\text {th }}$ century, two artillery batteries, named respectively as "High", armed with four 95 mm guns, and "Low", armed with small calibre guns, and on the Grand Gouin pointe a mortar battery located in an unknown position (Glad Patrimoine de Bretagne 2002a; Glad Patrimoine de Bretagne 2006a; Glad Patrimoine de Bretagne 2006b; Truttmann 1975).

\section{The Goulet Mound German Defences}

In order to improve the defences of the Goulet, during the period of the Occupation 1940-1944 the German Kriegsmarine (War Fleet) constructed, among other on the northern side of the Goulet mound near the pointe Saint Mathieu, the M.K.B. "Holtzendorf", 1/M.A.A 262/Stp. Re 305 (Marine Kuste Batterie, 1/Marine Artillerie Abteilung 262/Stützpunkt Re305-Navy Coastal Battery, 1/Marine Artillery Division 262/Support Point Renan 305) armed with 4 x 150 mm guns under $S K$ (Sonder Konstruction - Special Construction) bunkers (Tomezzoli, 2015) and the M.K.B. "Graf Spee", 5/M.A.A. 262/Re 503 armed with $4 \times 280 \mathrm{~mm}$ S.K. L/40 guns, 3 in open gun emplacements and 1 under $S K$ bunker (Glad Patrimoine de Bretagne, 2005). On the southern side, the German Heer (Army) constructed near Camaret the H.K.B.1274/StP C342 (Heer Kuste Batterie 1274/Stutzpunkt C342-Army Coastal Battery 1274/Support Point Camaret 342) (Figure 1) comprising $2 \times 7.5 \mathrm{~cm} \mathrm{C/97}$ guns each under bunker M670 on the Petit Gouin pointe and $4 \times 220 \mathrm{~mm} K 532$ long range guns in open gun emplacements on the Grand Gouin pointe (Glad Patrimoine de Bretagne 2002b; Rapport Pinczon du Sel, 1947-1948).

Because no allied sea attack came, like that of $25^{\text {th }}$ August1944 by HMS Warspite on M.K.B. "Graf Spee”, H.K.B.1274 did not operate actively for the defence of the Goulet.

However, it was object of a massive allied bombardment (Figure 2). When this took place is not completely clear (Florentin, 2008). However, it probably took place on $3^{\text {rd }}$ September 1944 during Mission 601 against the Crozon peninsula, by $393 B 17$ of the $8^{\text {th }} U S A A F 3^{\text {rd }} B D$ (Bomber Division) supported by 15 $P 51$ and 49 P38 of the $8^{\text {th }}$ USAF FC (Fighter Command).

The bombardment report (Bohn, 1998) indicates raids on the following objectives:

1) Brest and peninsula: 09:36 - 10:58, bombs: $1203 \times 500$ lb GP (General Pur- 


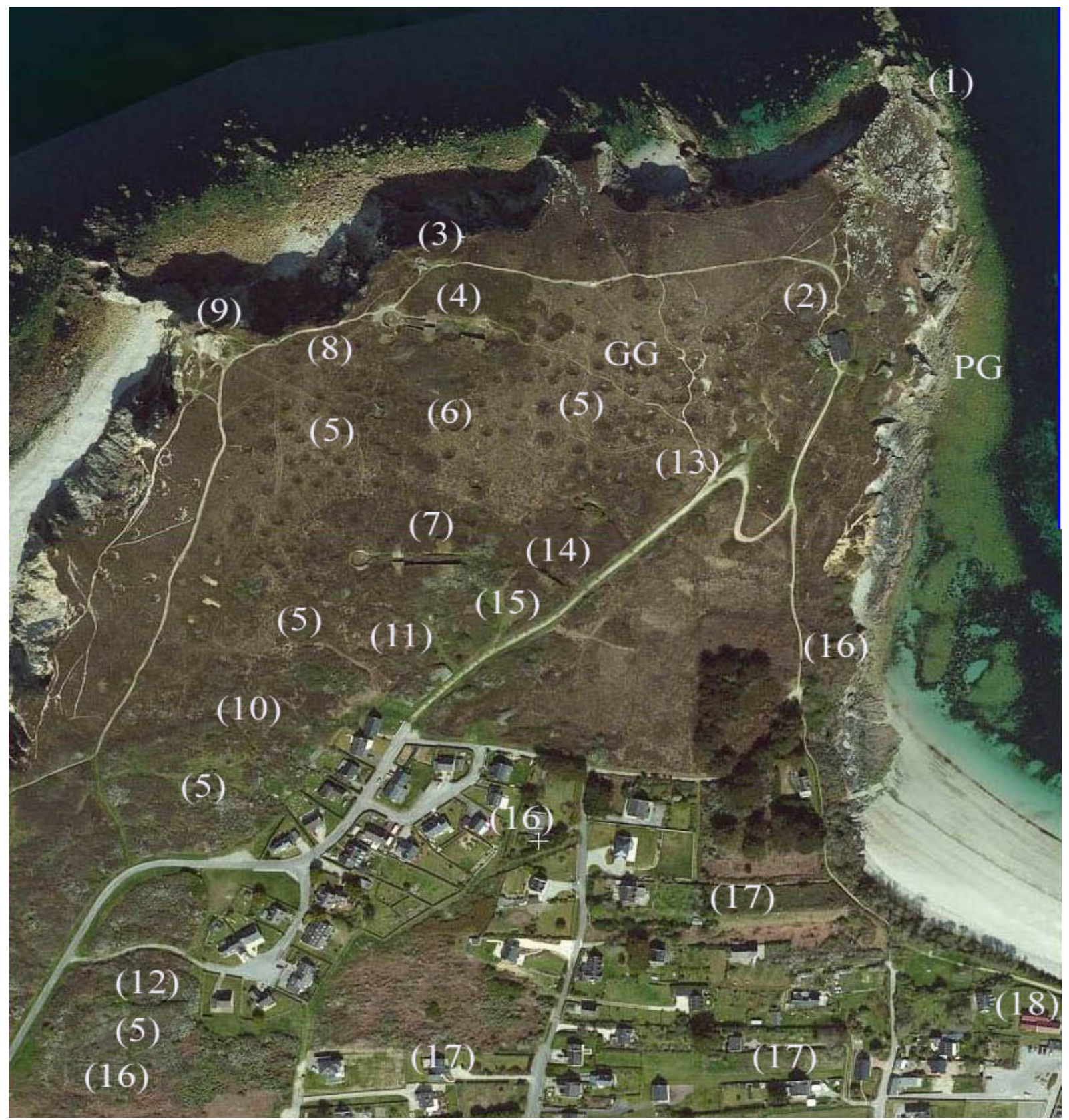

Figure 1. H.K.B. 1274-PG Petit Gouin pointe; GG Grand Gouin pointe; (1) platform and barrack; (2) $2 \times 2 \mathrm{~cm}$ Flak gun 30 emplacements; (3) reflector emplacement; (4) $1^{\text {st }}$ open gun emplacement; (5) bombarded areas; (6) square emplacement; (7) $2^{\text {nd }}$ open gun emplacement; (8) latrine; (9) observatory bunker; (10) destroyed $3^{\text {rd }}$ open gun emplacement; (11) destroyed 5 $\times$ C9 $75 \mathrm{~mm}$ gun emplacements; (12) destroyed $4^{\text {th }}$ open gun emplacement; (13) $3 \times$ possible French concrete, joined barracks; (14) H622 and $H 638$ bunkers; (15) H641 bunker; (16) security perimeter: metal barrier and tobrucks; (17) minefields; (18) Camaret sur Mer [GeoPortail].

pose), $4771 \times 100 \mathrm{lb}$ GP, $1480 \times 500 \mathrm{lb} \mathrm{SAP}($ Semi-Armor Piercing), $999 \times 260 \mathrm{lb}$ fragmentation, tot. 1037.9 tons delivered, 2 planes lost, 13 damaged;

2) Crozon-Kerret: 10:37 - 10:40, covered by explosions during two attack waves; 3) Kerloc'h: 10:10 - 10:51, military position, 15 explosions on the target site, 65 on the N-W beach, 60 on the nearby fields, 35 bombs on the Kerloc'h bridge (HSO 10:15); 4) Kérinel: 10:18, 10:28 - 10:43, military position, 60 explo- 


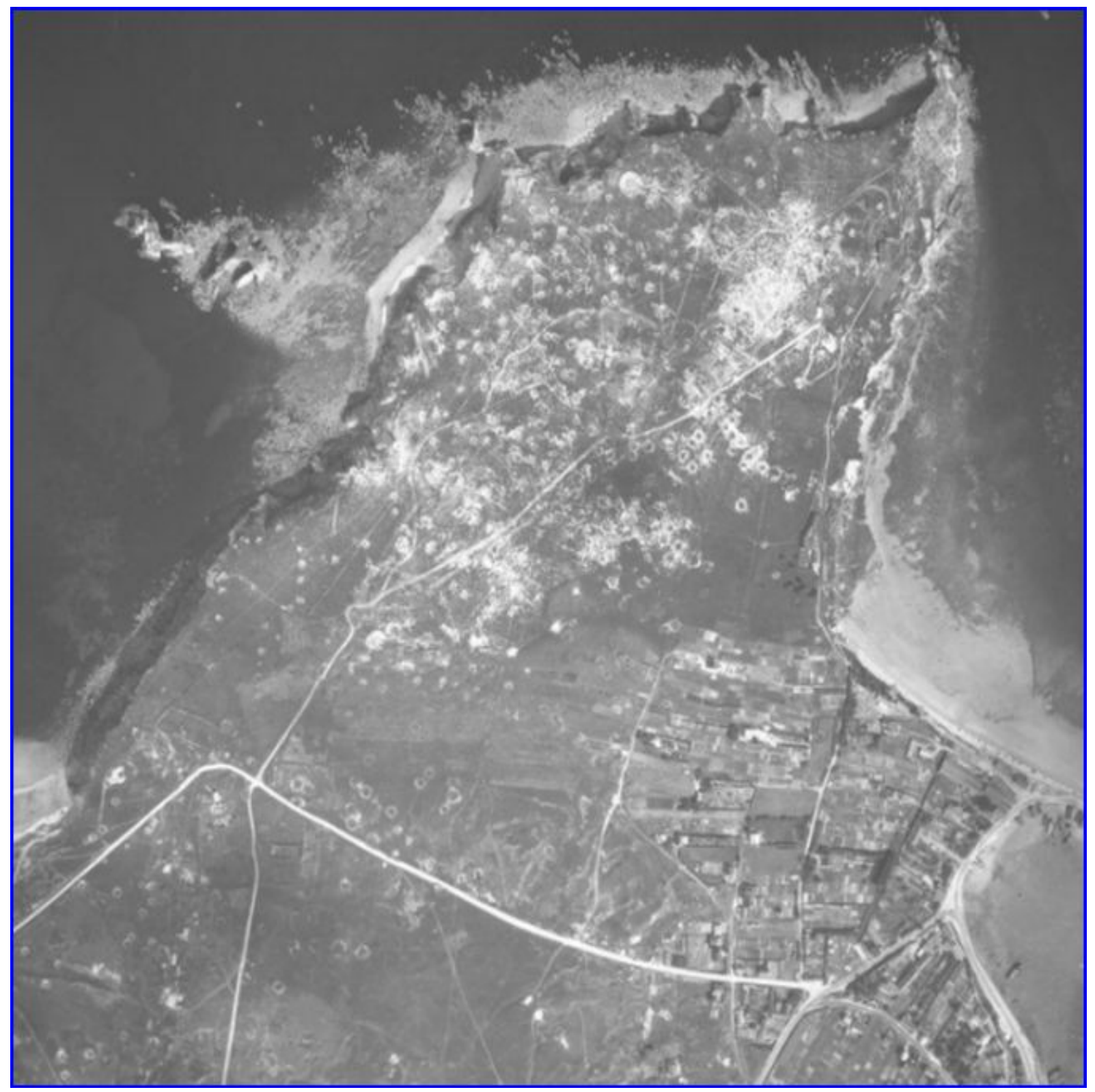

Figure 2. Mission 601 bombardment of H.K.B. 1274-C0417-0301_1951_CDP3760_0984, n984, 1/5154, 27/07/1951 [GeoPortail].

sions, some small boat touched;

5) Crozon: 10:22, 10:22 - 10:32, military position, about 15 explosions on the zone; 6) Kerguillo: 09:42 - 09:58, 10:21, military position, about 20 explosions on the S-W side of the zone, other explosions at the E-N-W of the position, 25 on the beach $3500 \mathrm{~m}$ from the target; 7) Telgruc and Penquer le Craon: HSO: 09:36, 10:16 -10.18 defended positions, $60 \times$ GI, $25 \times F F I$ (French Forces of the Interior) and $25 \times$ civilians killed; 8) Brest-Pont Scorff : 10:15 - 10:18, coastal battery, about 75 explosions; 9) Brest-Tregoudan: 10:20 - 10:47, coastal battery, 50 explosions outside the target zone;

10) Brest-pointe des Espagnols: 10:22 - 10:23, heavy coastal battery and torpedo battery, some bombs fallen into the sea; 
11) Camaret-Fort de Quélern: 10:26, about 15 bombs touched the Fort; 12) Lanvéoc-Poulmic: 10:03, 10:09, 10:10, 10:27, defended position, about 100 explosions inside 50 - $100 \mathrm{~m}$ from the target, other at $300 \mathrm{~m}$ from the target; 13) Morgat: 10:26, 10:58, 11:00, artillery battery, at least 100 bombs on the target.

Because no German heavy coastal battery existed on the pointe des Espagnols (10), the only heavy coastal battery bombarded was surely H.K.B.1274, only 4 $\mathrm{km}$ away.

The bombardment of H.K.B.1274 (Figure 2) was successful. Many of its components on the Grand Gouin pointe were completely destroyed or seriously damaged. The components on the Petit Gouin pointe, protected by a cliff or intentionally left aside, escaped the bombardment.

The visit of the H.K.B.1274 site took place on $27^{\text {th }}$ December 2016.

\section{Petit Gouin Components}

The H.K.B.1274 components identified on the Petit Gouin (Small White) pointe (Figure 3 ) were the followings.

A $1^{\text {st }} R 670\left(48^{\circ} 17^{\prime} 08.52^{\prime \prime} \mathrm{N}, 04^{\circ} 36^{\prime} 03.76^{\prime \prime} \mathrm{W}\right)$ (Figure 4 ) for $7.5 \mathrm{~cm} \mathrm{C/97}$ Schneider gun. It presented a well preserved concrete structure decorated by contemporary, coloured graffiti, without damages due to the bombardment or combats. The narrow rear aperture of the fire room close to the cliff suggested that the hosted gun was detached from its mobile carriage, introduced into the fire room through its front aperture and mounted on a support anchored to fixing bolts in a square aperture on the floor of the room. The fire room was empty,

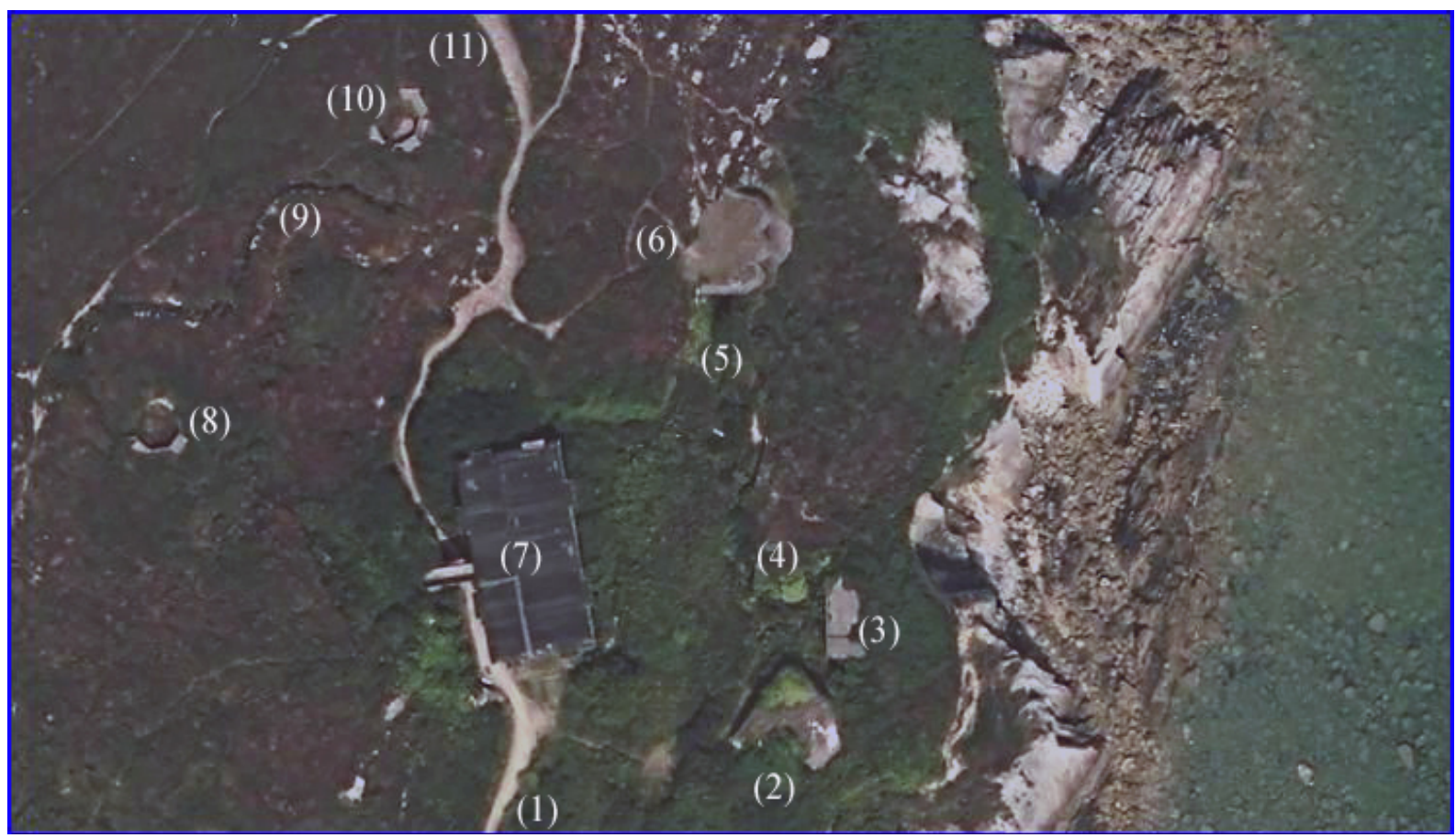

Figure 3. Petit Gouin pointe (1) access pathway, (2) $1^{\text {st }} R 670$, (3) $1^{\text {st }}$ barrack, (4) $2^{\text {nd }}$ barrack, (5) concrete platform, (6) $2^{\text {nd }}$ $R 670$, (7) French crenelated guardhouse, (8) $1^{\text {st }} 2 \mathrm{~cm}$ Flak gun 30 emplacement, (9) connection trench (10) $2^{\text {nd }}$ Flak gun 30 emplacement, (11) pathway to the Grand Gouin pointe [GeoPortail]. 


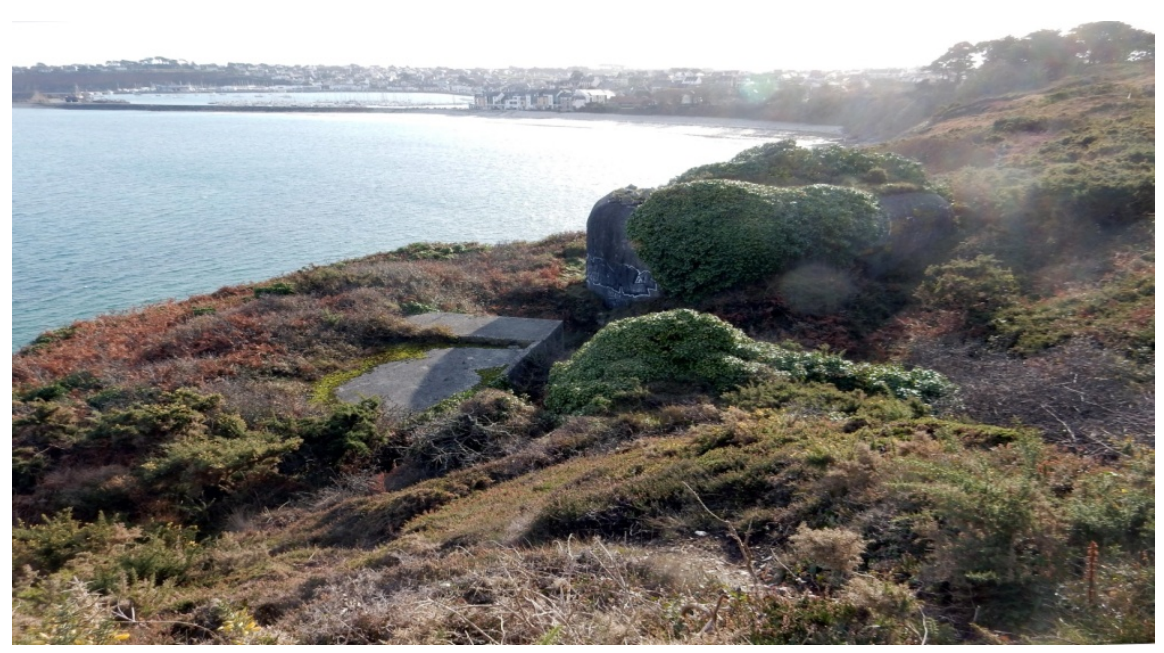

(a)

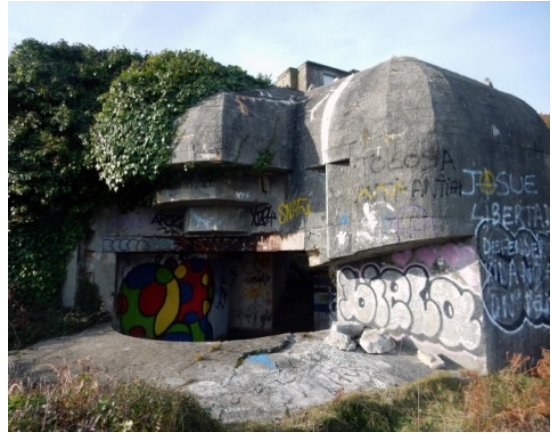

(b)

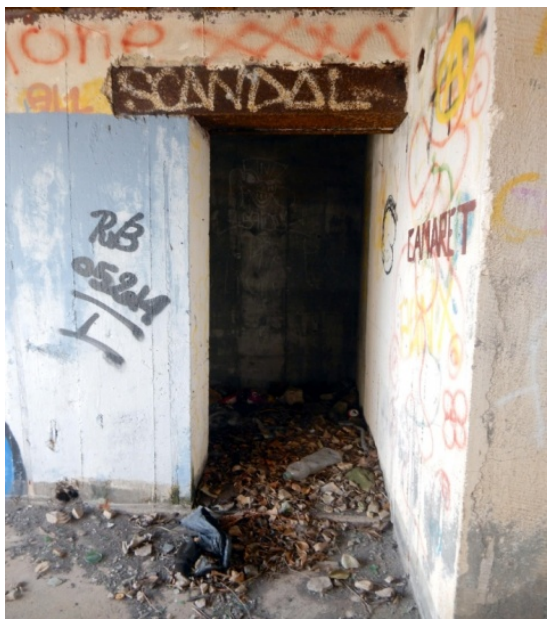

(d)

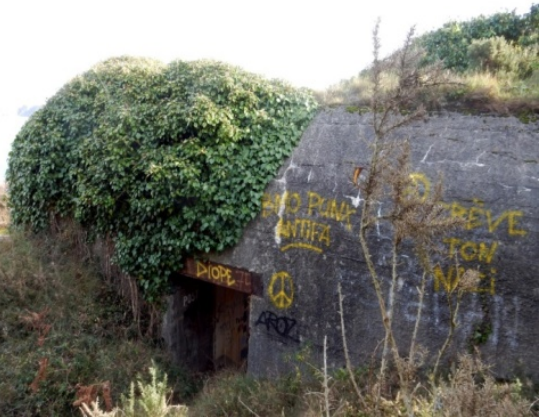

(c)

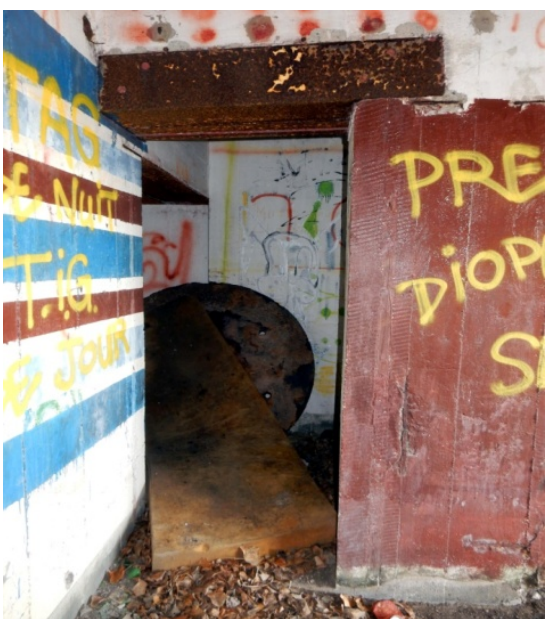

(e)

Figure 4. $1^{\text {st }} R 670$ (a) view from the $2^{\text {nd }} R 670$, on the left $1^{\text {st }}$ barrack, on the foreground Camaret sur Mer; (b) front side with with splinter guards, on the top left the French crenelated guardhouse of 1859; (c) rear side with entrance to the fire room close to the cliff; (d) ammunition room; (e) combat gas extraction system room.

deprived of its original furniture and decorated by coloured graffiti. On the walls, no traces of a thermal insulation system. The fire room and the combat gas extraction system room preserved some rusted portion of conduits. The metallic ceiling preserved two joints for the gun lifting and the grids of the combat 
gas extraction system.

A $1^{\text {st }}$ barrack $\left(48^{\circ} 17^{\prime} 08.86^{\prime \prime} \mathrm{N}, 04^{\circ} 36^{\prime} 03.54^{\prime \prime} \mathrm{W}\right.$ ) (Figure 5 ), close to the $1^{\text {st }}$ $R 670$, about $4 \times 8 \mathrm{~m}$. It was partially buried in the terrain. Its emerging, concrete structure was well preserved without damages due to the bombardment or combats. Two windows, opened towards the cliff, provided light to an internal, single room preserving its probably original wall pale, ochre painting, covered by contemporary, coloured graffiti, and ceiling white painting. On the ceiling a chimney hole confirmed that it was habitable, notwithstanding the absence of a latrine and traces of electrical elements. Probably it was used as guardhouse. All the original furniture disappeared and the room was partially filled with terrain fell from the cliff through the windows. The traces of the formwork elements visible on the external walls, typical of the German masonry, confirmed that it was of German construction.

A $2^{\text {nd }}$ barrack (Figure 6 ), close to the $1^{\text {st }}$ one, about $4 \times 5 \mathrm{~m}$. It was completely buried in the terrain. Its emerging concrete structure was well preserved without damages due to the bombardment or combats. Two windows, opened towards the cliff, provided light to an internal, single room preserving its probably original wall pale, ochre painting, covered by contemporary, coloured graffiti, and ceiling white painting. The absence of a chimney hole on the ceiling, a kitchen, a latrine and traces of electrical elements confirmed that it was not habitable and probably used as material depot. All the original furniture disappeared and

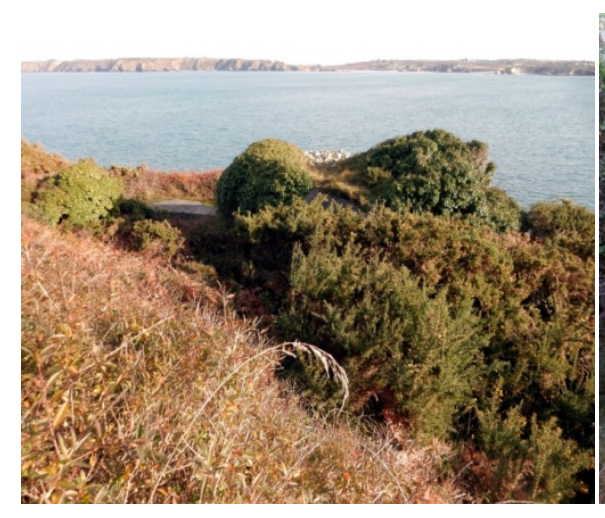

(a)

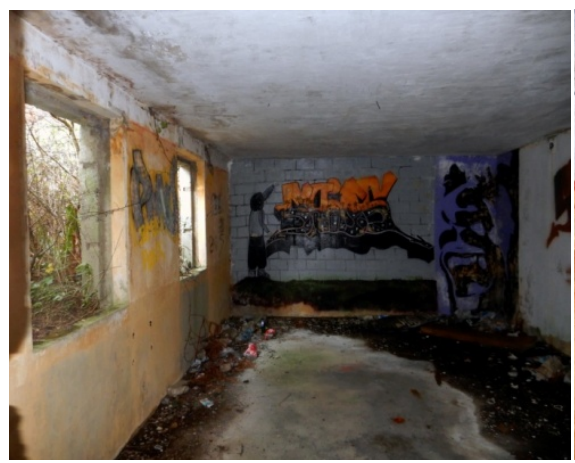

(c)

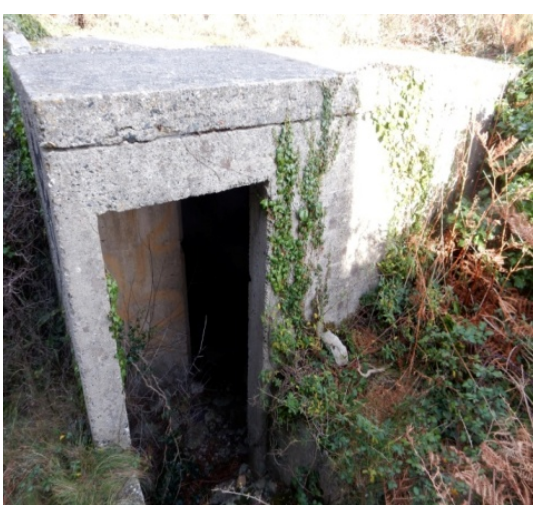

(b)

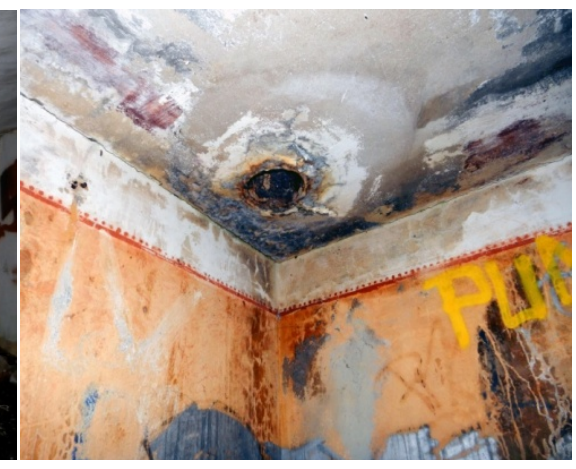

(d)

Figure 5. $1^{\text {st }}$ barrack (a) coverage, on the top Trez-Rouz beach "British Death"; (b) entrance; (c) lodging room; (d) chimney hole probably for Festungshofen (fortress oven) WT80. 


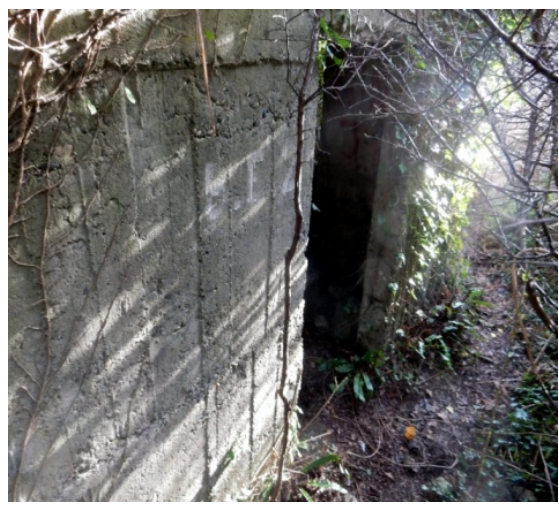

(a)

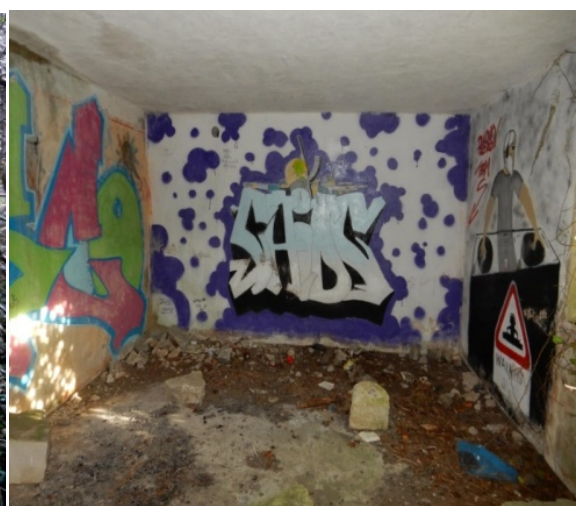

(b)

Figure 6. $2^{\text {nd }}$ barrack (a) entrance; (b) internal, single room.

the room was partially filled with terrain fell from the cliff through the windows. It too was of German construction.

A $2^{\text {nd }} R 670\left(48^{\circ} 17^{\prime} 10.06^{\prime \prime} \mathrm{N}, 04^{\circ} 36^{\prime} 04.07^{\prime \prime} \mathrm{W}\right)$ (Figure 7) for $7.5 \mathrm{~cm} \mathrm{C} / 97$ Schneider gun, about $40 \mathrm{~m}$ north from the $1^{\text {st }}$ one. It presented a well preserved concrete structure decorated by small, contemporary, coloured graffiti, without damages due to the bombardment or combats. It was accessible from the two barracks through a concrete staircase bringing to a concrete platform provided with two fixation bolts positions for gun or projector supports. At the platform end, a corridor entrance brought to the ammunition room, the combat gas extraction system room and the rear side opening of the fire room of the bunker. The fire room was empty, deprived by its original furniture and decorated by coloured graffiti. On the walls, no trace of a thermal insulation system. The fire room and the combat gas extraction system room preserved some rusted portion of conduits. The metallic ceiling preserved two joints for the gun lifting and the grids of the combat gas extraction system. At its end, the corridor further gave access to another barrel vault corridor, probably of French construction, carved into the cliff, having cable supports on the walls. This corridor, folded at $90^{\circ}$, gave access to an empty room about $5 \times 5 \mathrm{~m}$ of unknown purpose.

A French crenelated guardhouse $\left(48^{\circ} 17^{\prime} 09.09^{\prime \prime N}, 04^{\circ} 36^{\prime \prime} 05.08^{\prime \prime W}\right)$ (Figure 7 (a)), $10 \times 20 \mathrm{~m}$ (Dion, 1996). It was closed and not accessible to the public. The underground floor hosted a cistern. The first floor, partially protected by the cliff, comprised an access portal, 4 rooms for lodgements and services of the French garrison and 5 smaller rooms for hosting services, ammunitions and artillery materials. The second floor was the artillery terrace and was covered and rendered habitable in the first half of the $20^{\text {th }}$ century. It comprised an access portal connected to the cliff by a bridge and 8 turrets with louvers (Glad Patrimoine de Bretagne, 2002a).

\section{Grand Gouin Components}

The H.K.B. 1274 components identified on the Grand Gouin (Great White) pointe (Figure 1) were the followings.

A platform $\left(48^{\circ} 17^{\prime} 13.12^{\prime \prime} \mathrm{N}, 04^{\circ} 36^{\prime} 04.47^{\prime \prime} \mathrm{W}\right.$ ) (Figure 8), about $4 \mathrm{~m}$ diam. and 


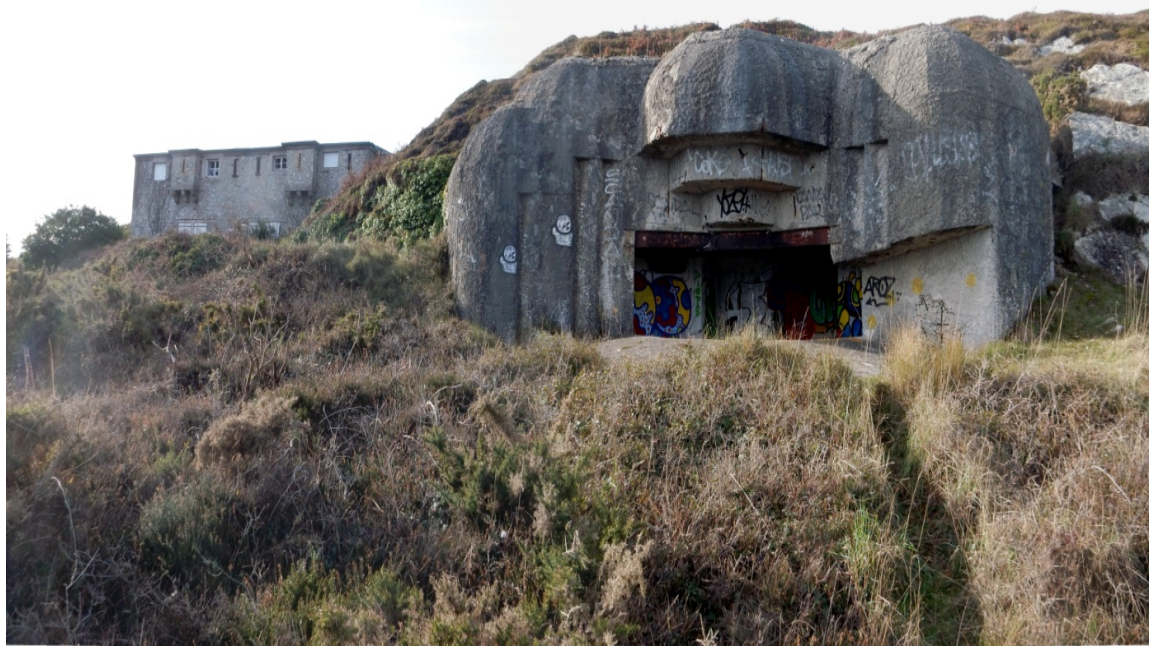

(a)

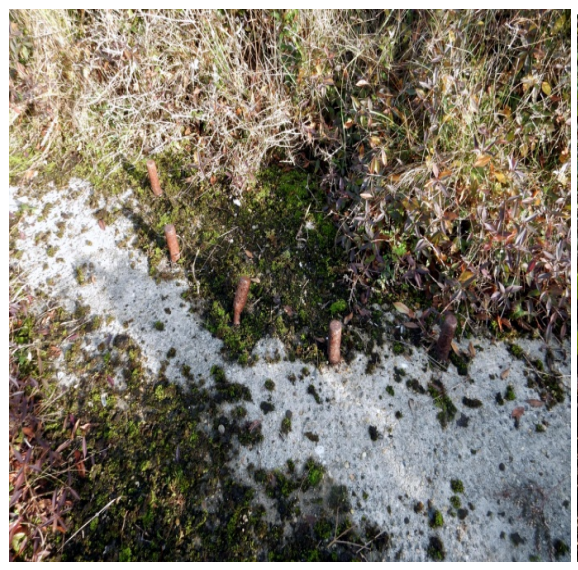

(b)

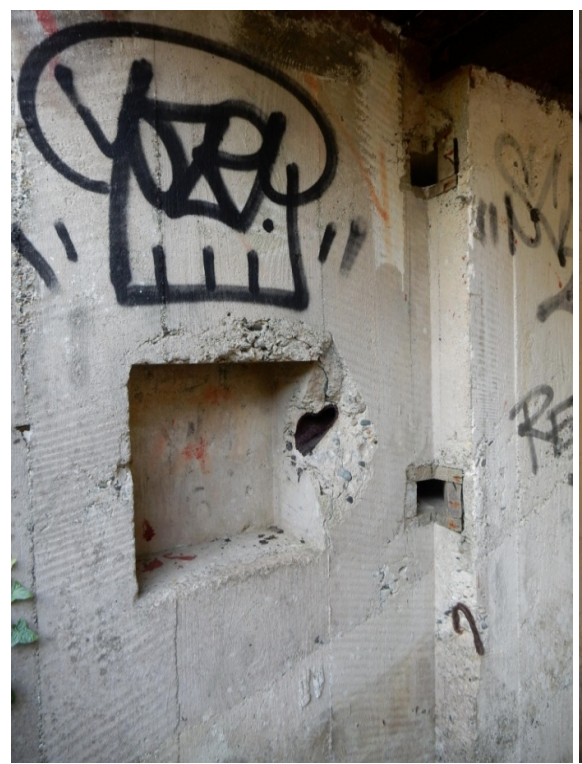

(d)

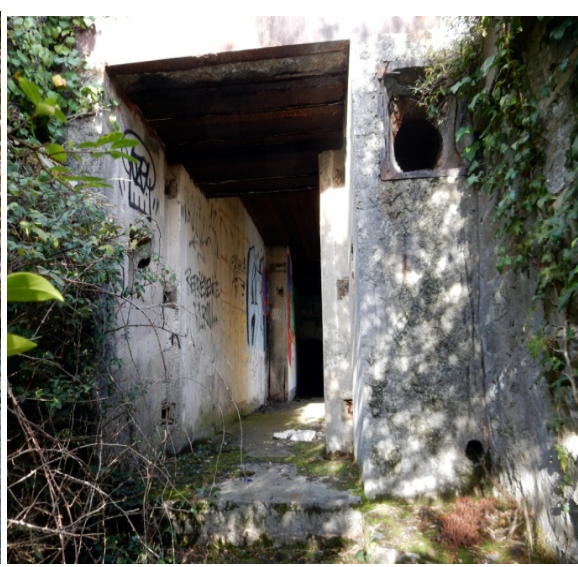

(c)

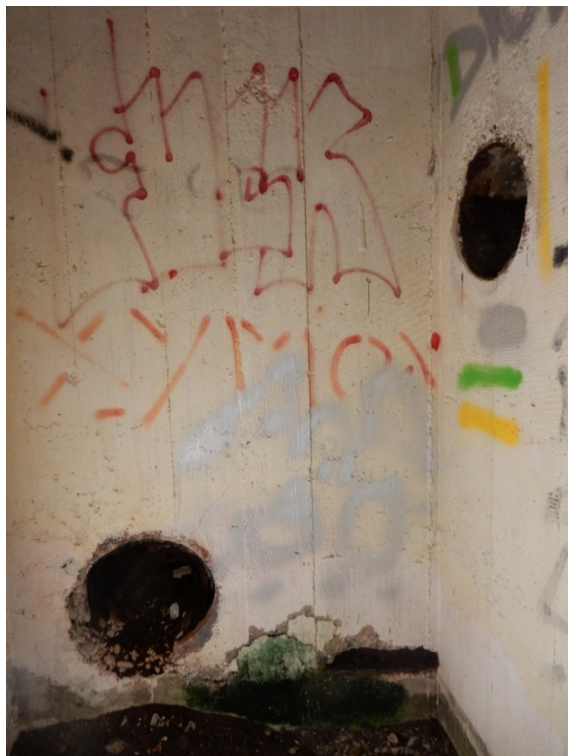

(e) 


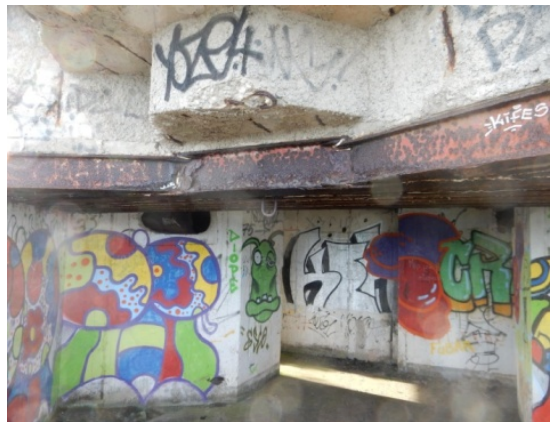

(f)

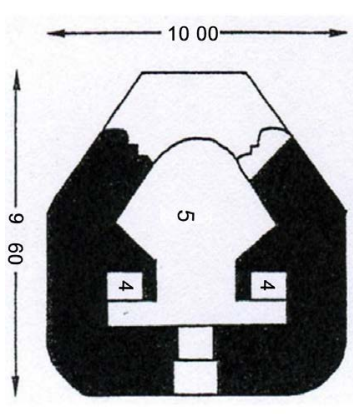

(h)

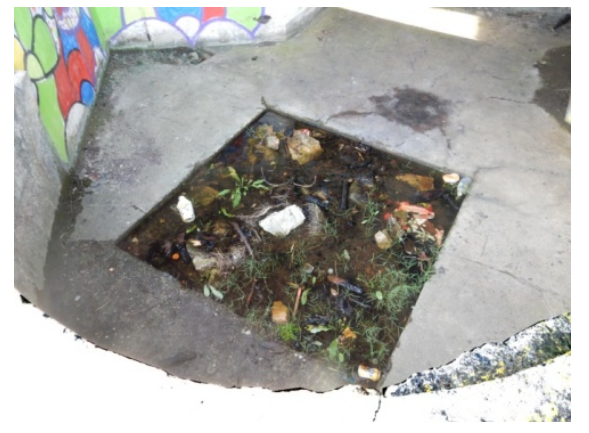

(g)

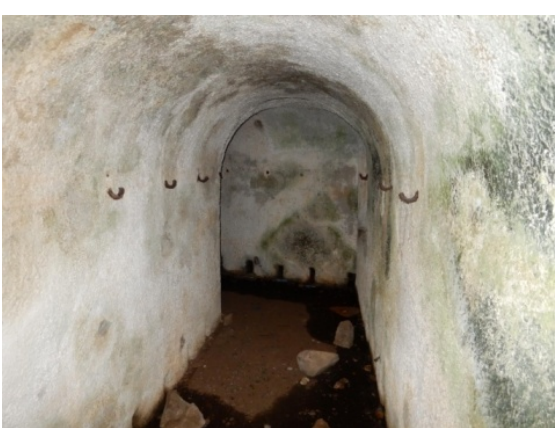

(i)

Figure 7. $2^{\text {nd }} R 670$ (a) fire room front side aperture with splinter guards, on the upper left the 1859French crenelated guardhouse; (b) concrete platform with one of the two fixation joints position for a gun or projector support; (c) corridor entrance, on the right exhausted combat gas conduit niche; (d) niches at the bunker entrance; (e) combat gas extraction system room, rusted conduits rests; (f) fire room entrance, metallic ceiling with joint for gun lifting; (g) square gun emplacement with plied fixing bolts; (h) R670 plan. 4 ammunition room and combat gas extraction system room, 5 fire room (Rudi, 1998); (i) barrel vault corridor to an empty room of unknown purpose carved into the cliff.

$20 \mathrm{~cm}$ thick. It preserved an erected part, about $50 \mathrm{~cm}$ high, of its original parapet. A collapsed portion along a fracture line crossing its center leaned on the ground masking the platform support. The collapse was due either to a structural failure or to the vibrations induced on the platform by the bombardment. An octagonal incision on its surface confined small triangular incisions probably for the adhesion of a concrete coverage. On the platform, mixed in the concrete, the pebbles of the Ero Vili (Tomezzoli \& Marzin, 2015) were clearly visible.

A barrack $\left(48^{\circ} 17^{\prime} 12.15^{\prime \prime} \mathrm{N}, 04^{\circ} 36^{\prime} 04.32^{\prime \prime} \mathrm{W}\right.$ ) (Figure 8), about $8 \times 4 \mathrm{~m}$. It presented a well preserved concrete without damages due to the bombardment (Figure 9) or combats. A window provided light to an internal, unpainted, single room, covered by contemporary coloured graffiti. Although achimney hole in the ceiling, a kitchen, a latrine and of traces of electrical elements were absent, its position near the platform suggests that it was used for lodging the personnel in service at the platform. The traces of the formwork elements visible on the external walls confirmed that it was of German construction.

A rectangular component $\left(48^{\circ} 17^{\prime} 12.36^{\prime \prime} \mathrm{N}, 04^{\circ} 36^{\prime} 12.45^{\prime \prime} \mathrm{W}\right)$ (Figure 8), about 5 $\times 3 \mathrm{~m}$ emerged at the ground level. It presented well preserved concrete sides 50 $\mathrm{cm}$ thick and its interior was filled by a concrete blocks and terrain. Its purpose is unknown. 


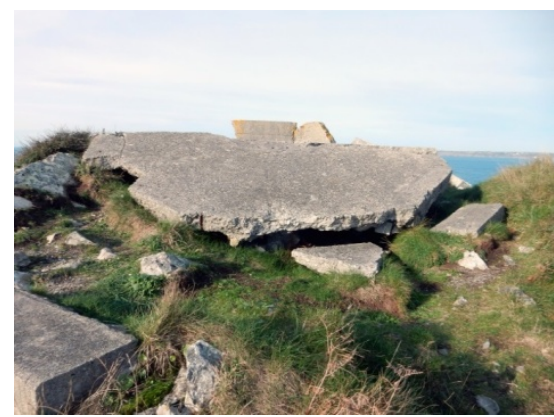

(a)

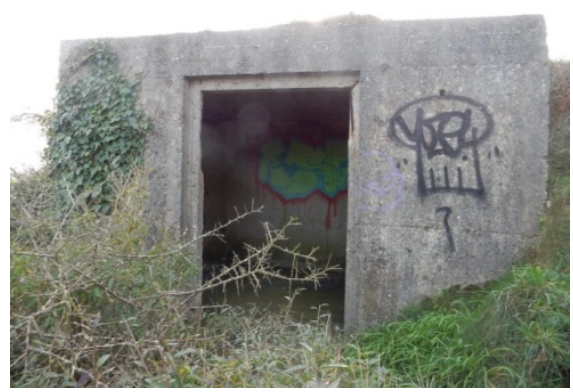

(c)

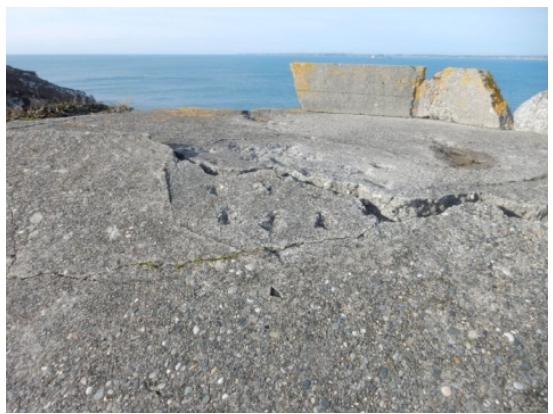

(b)

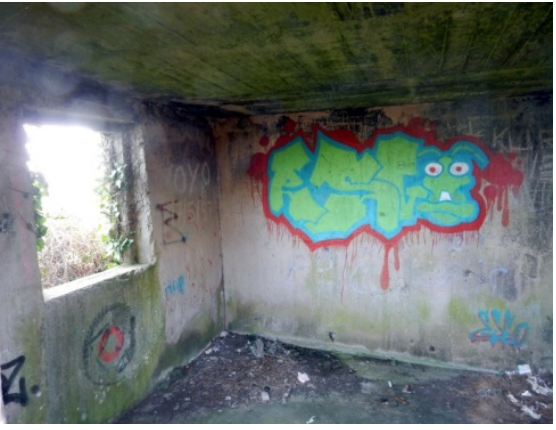

(d)

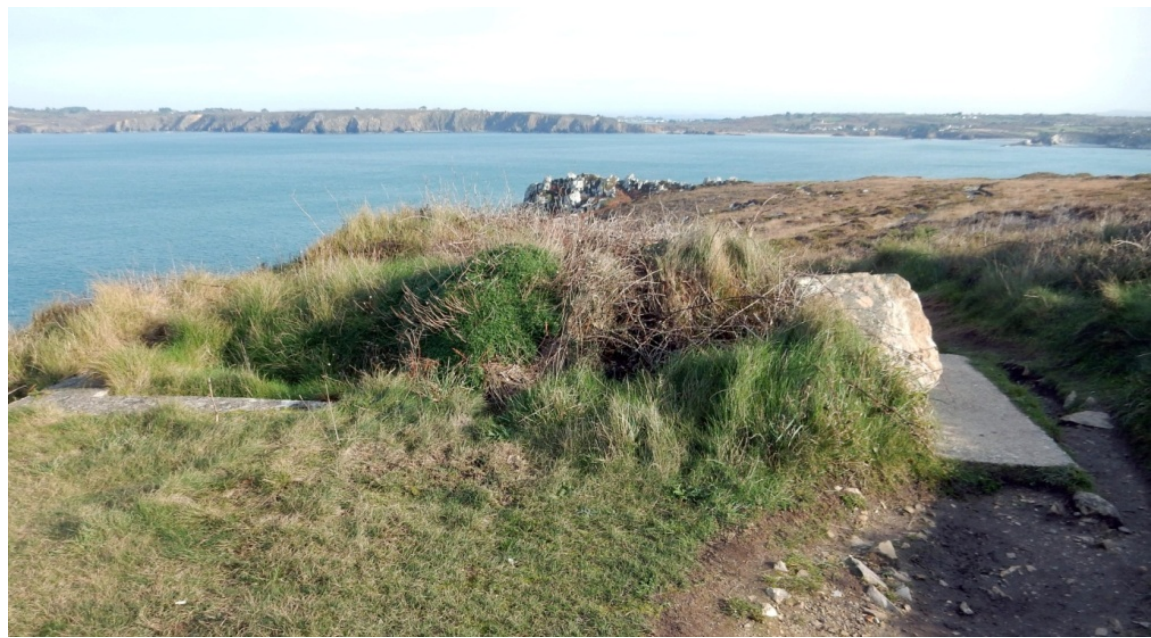

(e)

Figure 8. Grand Gouin pointe (a) platform, collapsed portion; (b) platform, fracture line and incisions; (c) barrack near the platform; (d) interior single room; (e) rectangular component of unknown purpose, on the left the Goulet mound, in the middle the Grand Gouin pointe.

A $1^{\text {st }} 2 \mathrm{~cm}$ Flak gun 30 emplacement $\left(48^{\circ} 17^{\prime} 09.46^{\prime \prime} \mathrm{N}, 4^{\circ} 36^{\prime} 06.92^{\prime \prime} \mathrm{W}\right)$ (Figure 10), $4 \mathrm{~m}$ internal diameter, buried in the terrain. It presented an emerging, concrete structure well preserved without damages due to the bombardment or combats. Octagonal in shape, it hosted the entrance on one side and ammunition stores on other four sides. At the centre, well preserved, the ground metallic support for the gun, provided bolt fixation screwed holes.

A $2^{\text {nd }}$ Flak gun 30 emplacement $\left(48^{\circ} 17^{\prime} 10.44^{\prime \prime} \mathrm{N}, 04^{\circ} 36^{\prime} 05.71^{\prime \prime} \mathrm{W}\right)$ (Figure 11), similar to the $1^{\text {st }}$ Flak gun 30 emplacement. It presented an emerging, concrete structure well preserved without damages due to the bombardment or combats. 


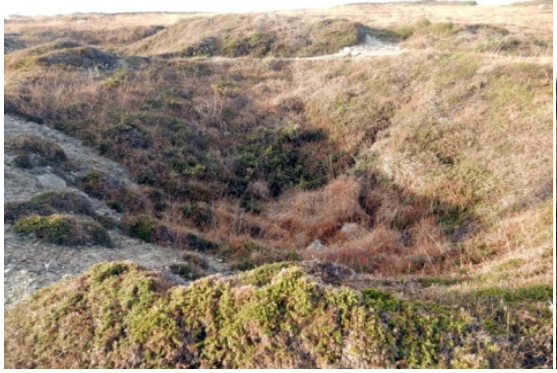

(a)

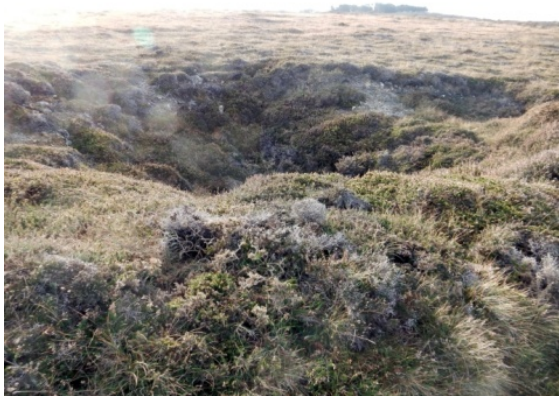

(c)

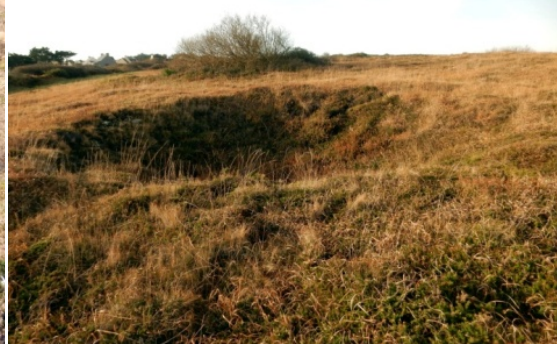

(b)

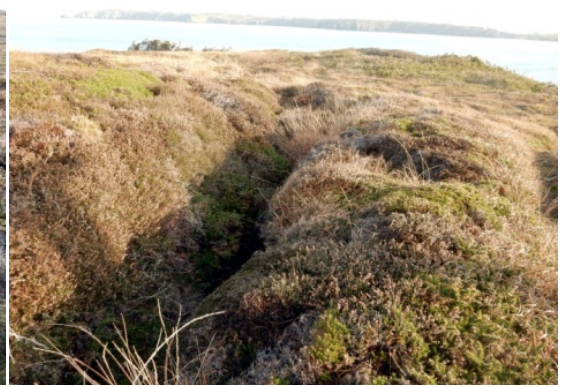

(d)

Figure 9. (a)-(c) bomb impact craters, (d), connection trench, in middle left the Grand Gouin pointe.

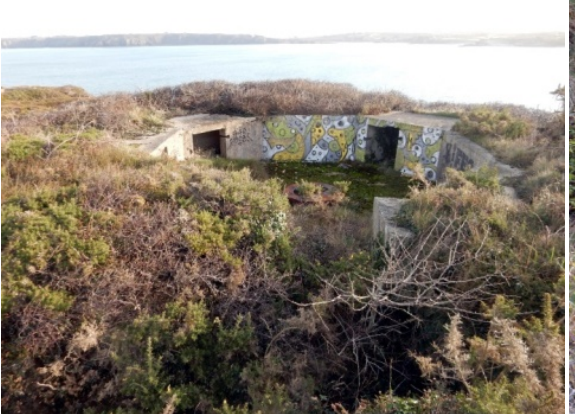

(a)

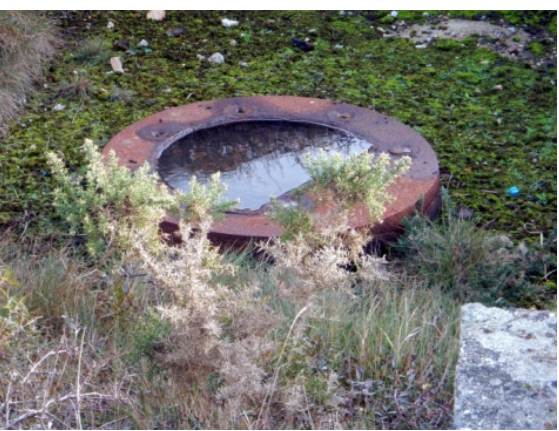

(b)

Figure 10. $1^{\text {st }} 2 \mathrm{~cm}$ Flak gun 30 emplacement (a) entrance and ammunition stores; (b) ground metallic support for the gun.

At the centre, well preserved, was the ground metallic support for the gun, equal to that of the $1^{\text {st }}$ gun 30 emplacement.

A $150 \mathrm{~cm}$ parabolic searchlight emplacement $\left(48^{\circ} 17^{\prime} 11.01^{\prime \prime} \mathrm{N}, 04^{\circ} 36^{\prime} 17.4^{\prime \prime} \mathrm{W}\right)$ (Figure 12) (Atlantikwall Co UK., 2016), about $5 \mathrm{~m}$ internal diameter. It was partially buried in the terrain and presented a well preserved emerging, concrete structure without damages due to the bombardment or combats. Octagonal in shape, it hosted a labyrinth entrance on one side and niches on each other internal sides. In the centre, well preserved, a triangular concrete base with three vertices recesses for the fixation of the projector support legs. Near its en-trance a rectangular, concrete emplacement, about $1.5 \times 2.5 \mathrm{~m}$, emerged from the terrain, possible access to lodging rooms under the emplacement. Leaning against an external side, a garage, $3.50 \times 2.50 \mathrm{~m}$, hosted a searchlight electrical generator 


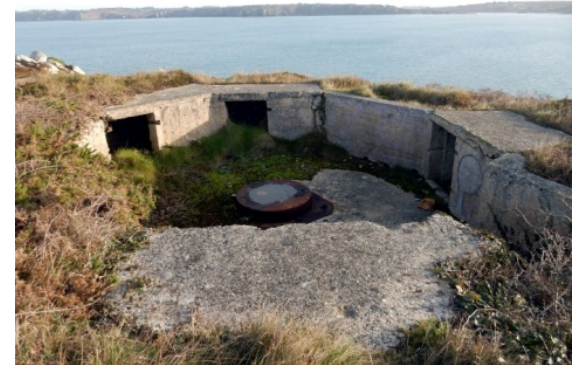

(a)

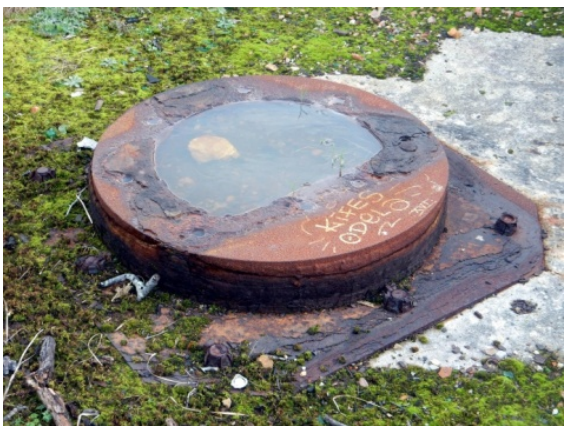

(b)

Figure 11. $2^{\text {nd }} 2 \mathrm{~cm}$ Flak gun 30 emplacement (a) entrance and ammunition stores; (b) ground metallic support for the gun.

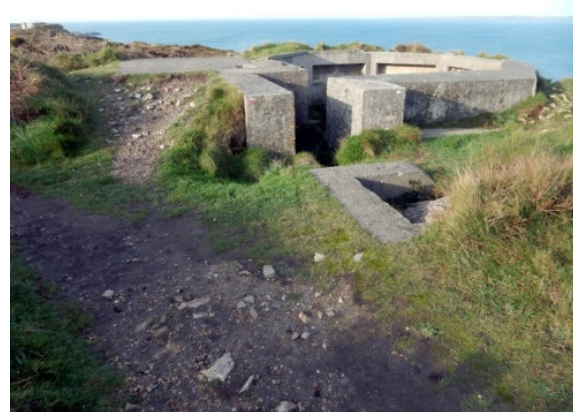

(a)

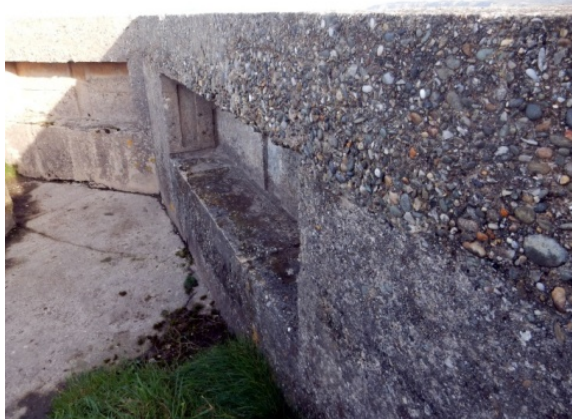

(c)

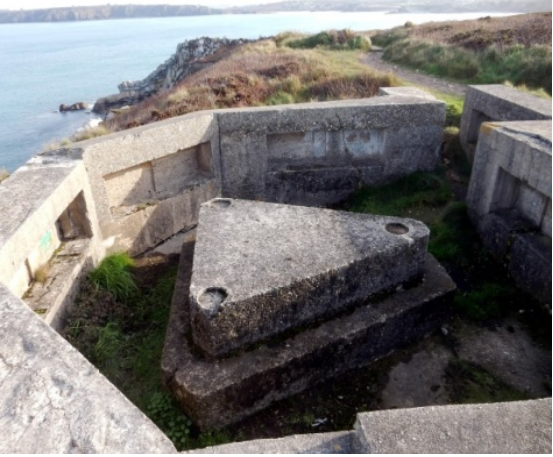

(b)

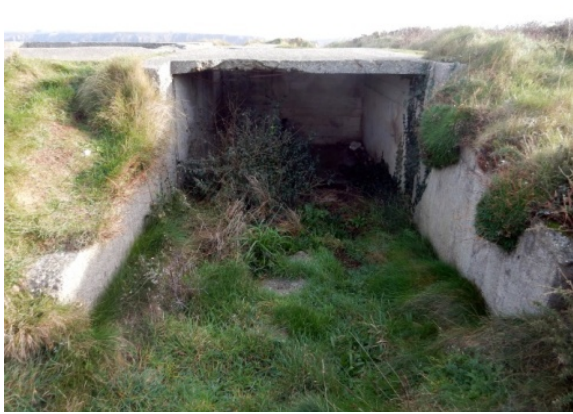

(d)

Figure 12. $150 \mathrm{~cm}$ search light emplacement (a) labyrinth entrance, on the left electric generator garage, on the right rectangular, concrete emplacement (b) interior with triangular concrete base with three recesses; (c) side niche; (d) electric generator garage.

mounted on a trailer, probably a standard diesel 8 cylinders engine delivering $200 \mathrm{~A}$ at $110 \mathrm{~V}$. The search on the terrain for other searchlight emplacements provided no result.

A $1^{\text {st }}$ gun open emplacement $\left(48^{\circ} 17^{\prime} 09.56^{\prime \prime N}, 04^{\circ} 36^{\prime} 16.86^{\prime \prime} \mathrm{W}\right)$ (Figure 13), about $65 \mathrm{~m}$ long and $22 \mathrm{~m}$ bright. It was an $S K$ construction formed by a concrete, circular gun emplacement, about $10 \mathrm{~m}$ diam., emerging at the terrain level, followed by two opposed right and left $V f 51 \mathrm{a}$ ammunition bunkers, and two opposed right and left $H 502 S K$ and $H 501 S K$ crew bunkers. A concrete access way ran along its sides to connect together all these constructions. The gun em- 


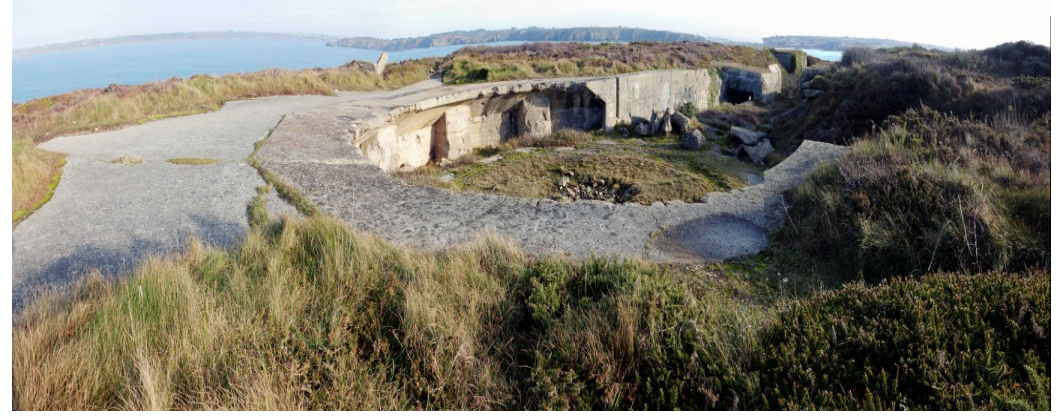

(a)

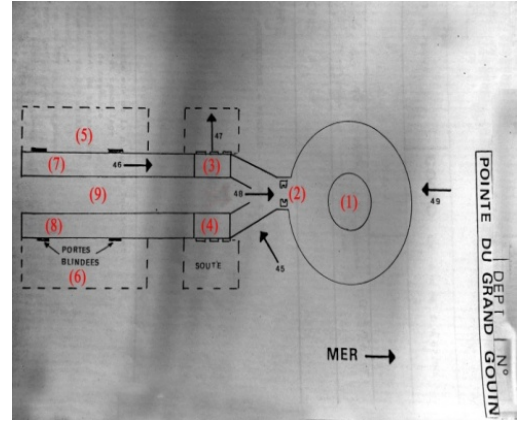

(b)

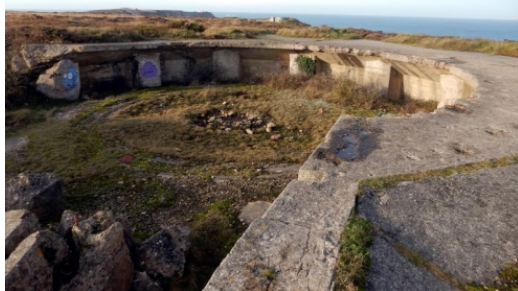

(d)

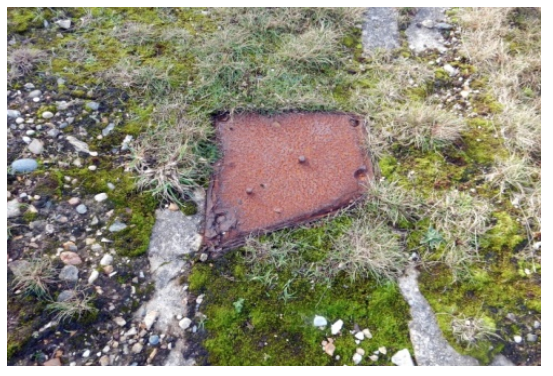

(f)

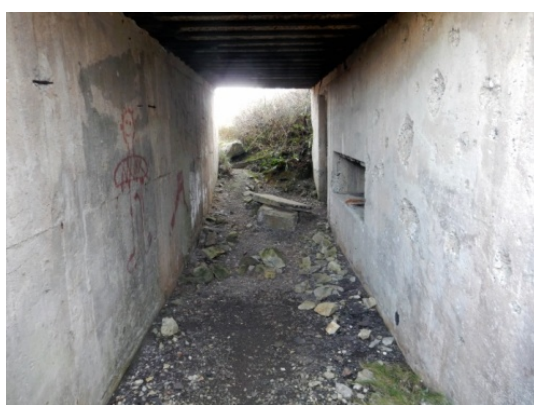

(h)

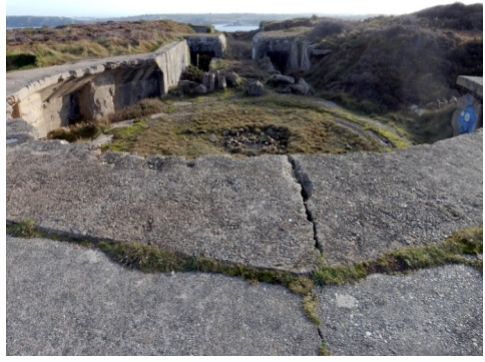

(c)

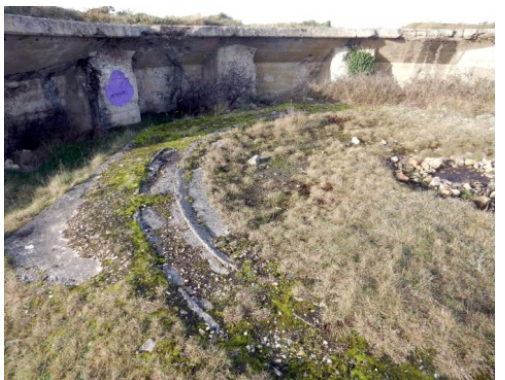

(e)

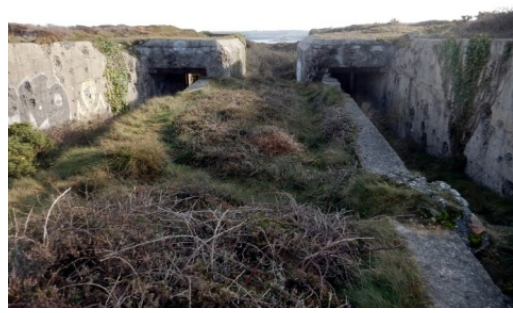

(g)

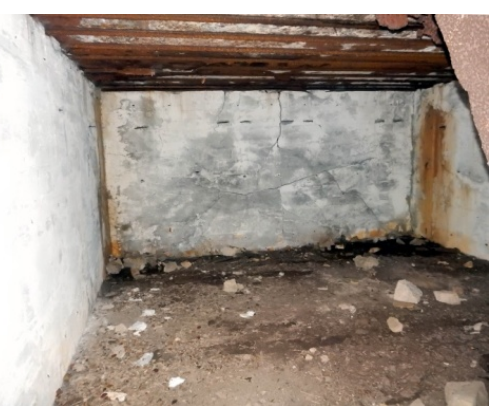

(i) 


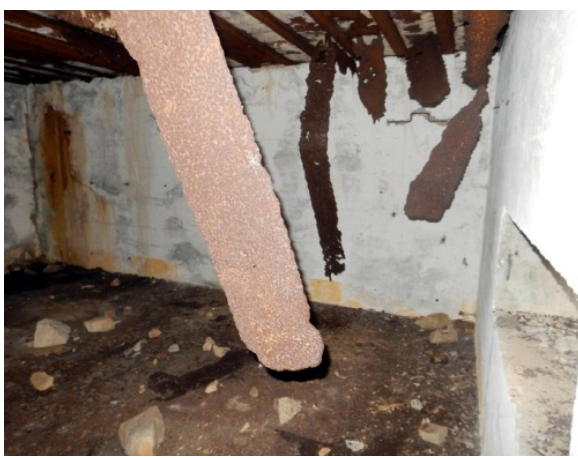

(j)

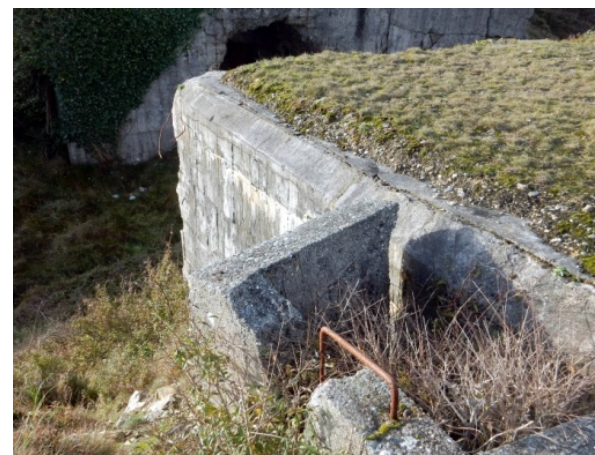

(1)

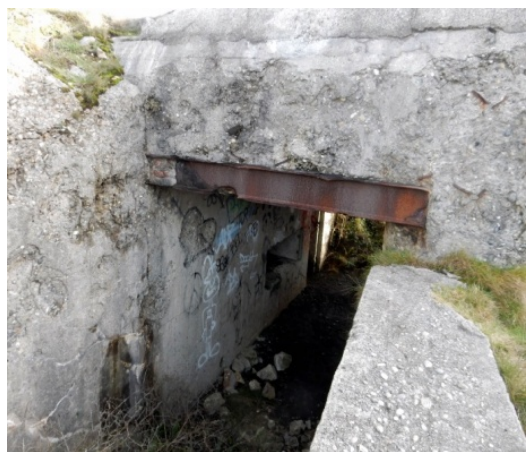

(k)

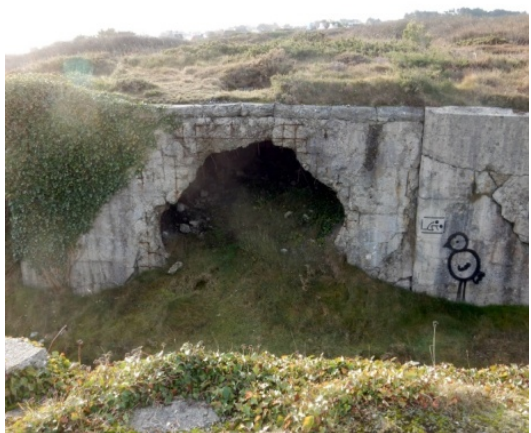

$(\mathrm{m})$

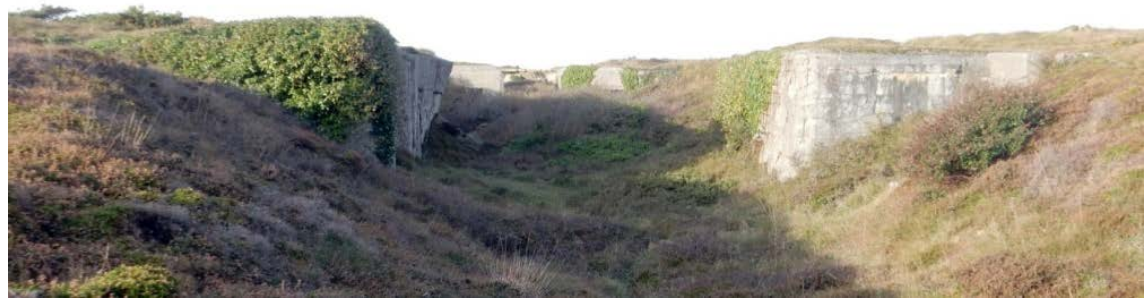

(n)

Figure 13. $1^{\text {st }}$ open gun emplacement (a) general view; (b) emplacement structure 11 circular gun emplacement, 2 emplacement entrance, 3 right Vf51a, 4 left Vf51a, 5 H502SK, 6 H501SK, 7 right branch of the access way, 8 left branch of the access way, 9 central rampart (Rapport Pinczon du Sel, 1947-1948); (c) circular gun emplacement and left and right Vf51a; (d) circular gun emplacement, ammunition niches and rests of the ground gun support, in the middle a bunker $R 636 a$; (e) trace of the fixation plates of the rail for turning the gun; (f) fixation plate of the circular rail; (g) central rampart and left and right $V f 51 a$, on the concrete walls impact hits of bomb splinters; (h) right Vf51a, corridor and opening of the ammunition room; (i) right $V f 51 a$, ammunition room; (j) right Vf51a, ammunition room; (k) left Vf51a; (l) H501SK escape conduit; (m) H502SK, disintegrated facade; (n) emplacement entrance and internal court, on the left $H 502 S K$, on the right $H 501 S K$.

placement preserved eight niches on its internal wall for storing ammunitions and materials and on the floor the trace of the fixation plates of the rail for turning the gun. A trapezoidal fixation plate provided with a bolt at each vertex and two protruding mounting pins was still at its place in the trace. The gun support at the centre of the gun emplacement disappeared. Two broken, concrete, square columns at the entrance of the gun emplacement, each provided with a deep vertical groove on two opposed sides in correspondence with two other vertical grooves on the internal wall of the gun emplacement suggested the gun em- 
placement could be isolated from the rest of the emplacement by inserting wooden planks in the grooves. A central rampart separated and protected the two Vf51 $a$ and the $H 501 S K$ and $H 502 S K$, and the branches of the access way.

The right Vf51a was crossed by the access way through its corridor. An entrance in the corridor gave access to a single ammunition room preserving on the walls the original white painting, traces of metallic joints and on the ceiling a rusty metallic cover in some parts detached. A rectangular wall aperture near the entrance allowed the rapid exchange of the ammunitions. All the original room furniture disappeared. The left Vf51a was in all similar to the right Vf51a and both the two presented a well preserved concrete structure, without damages due to the bombardment or combats. Only the walls protecting the access way branches showed impact hits of bomb splinters. The H501 SK had its entrances obstructed by the vegetation; therefore its interior was not accessible. On its exterior structure, a damaged escape conduit was still recognizable. The H502 SK was hit by a bomb which perforated its coverture by a hole of $2 \mathrm{~m}$ diam., devastated its interior, killed the occupants and disintegrated the front facade.

A latrine $\left(48^{\circ} 17^{\prime} 09.21^{\prime \prime} \mathrm{N}, 04^{\circ} 36^{\prime} 21.61^{\prime \prime} \mathrm{W}\right)$ (Figure 14), near the cliff, $1.50 \mathrm{x}$ $1.50 \mathrm{~m}$. It presented a well preserved concrete structure, decorated by contemporary, coloured graffiti, without damages due to the bombardment or combats. It served the personnel in service at a nearby observatory and fire direction bunker.

A coastal battery observatory and fire direction bunker $\left(48^{\circ} 17^{\prime} 09.19^{\prime \prime} \mathrm{N}\right.$, $04^{\circ} 36^{\prime} 23.54^{\prime \prime} \mathrm{W}$ ) (Figure 15). It presented, with respect to the corresponding standard models $R 636, R 636 a$ (Figure $15(\mathrm{~m})$ ), the presence of a concrete, uncovered observation post for one soldier armed with a machine gun at the rear side near its entrance and the absence of an upper covered rangefinder observatory on its coverage. The uncovered, observation post presented a sub-stantially well preserved concrete structure, only part of which lost by a possible constructional failure or by vibrations induced on the post by the bombardment. The upper covered observatory was probably judged not necessary in view of the unobstructed field of view toward the sea of its observation room or the possible attempt of simplify the architecture and saving material. A bomb hit the dome coverage of the observation room. The dome coverage, although damaged (Figure 15(k)), sustained the explosion without however avoiding damages to

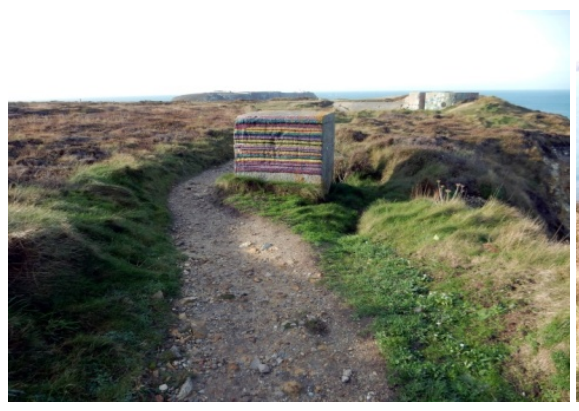

(a)

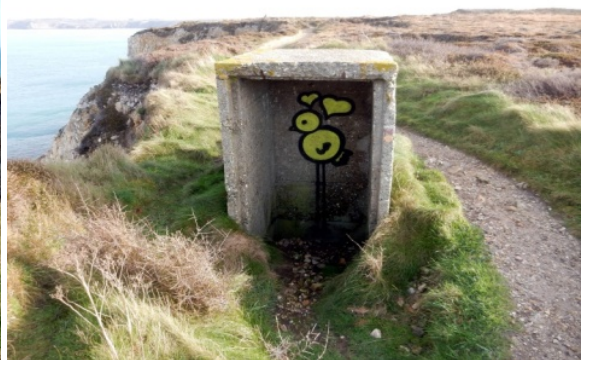

(b)

Figure 14. Latrine (a) rear side with $R 636 a$ in the foreground; (b) front side. 


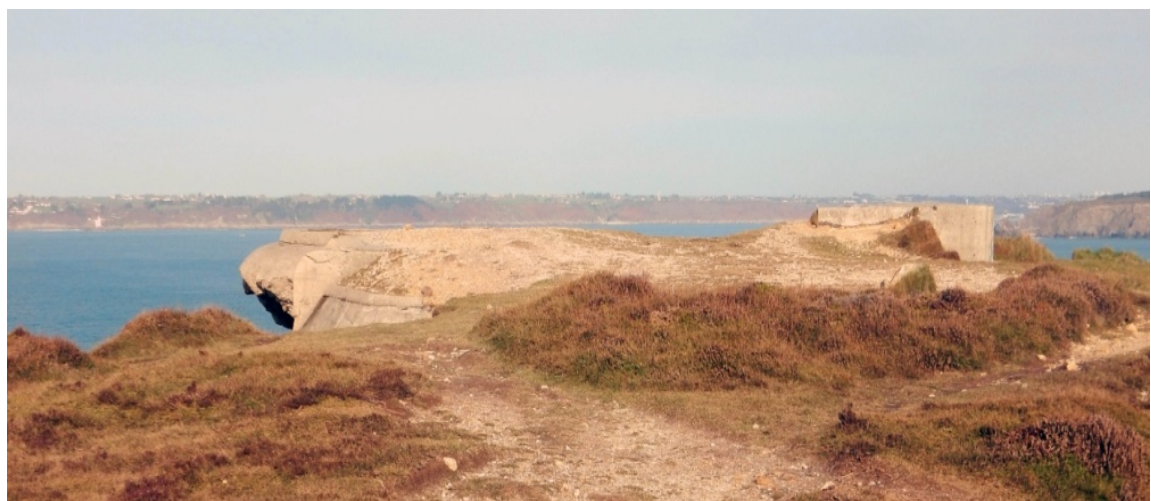

(a)

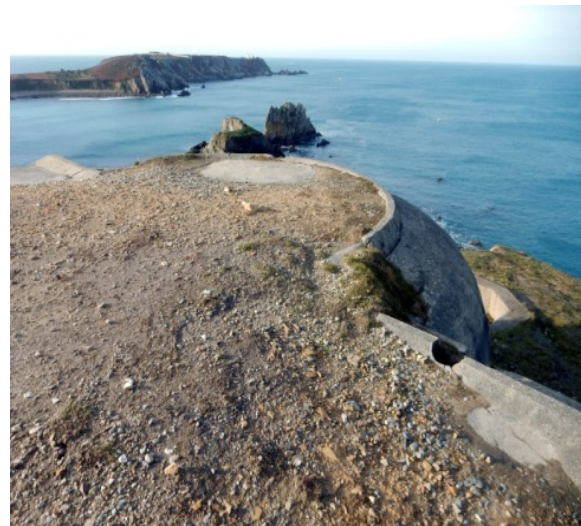

(b)

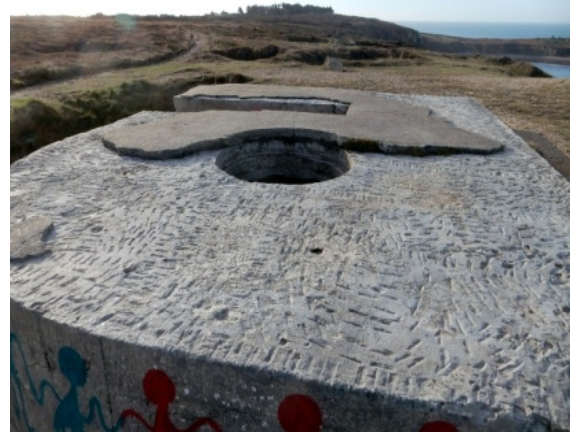

(d)

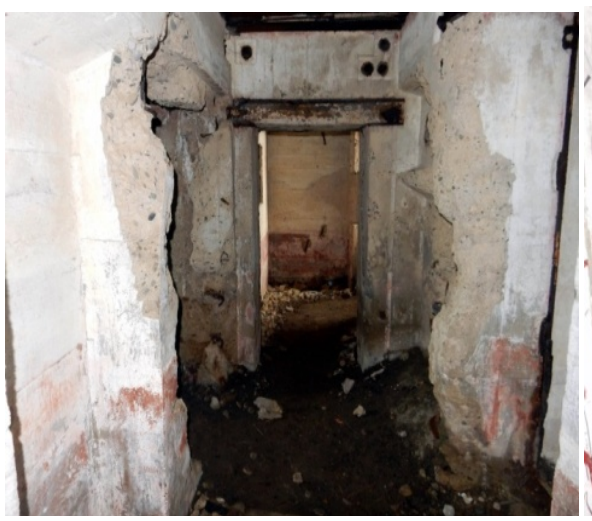

(f)

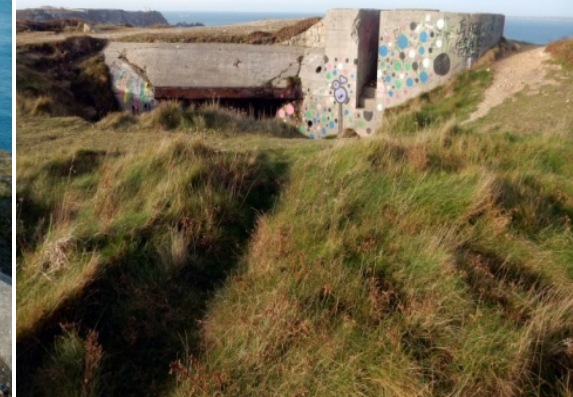

(c)

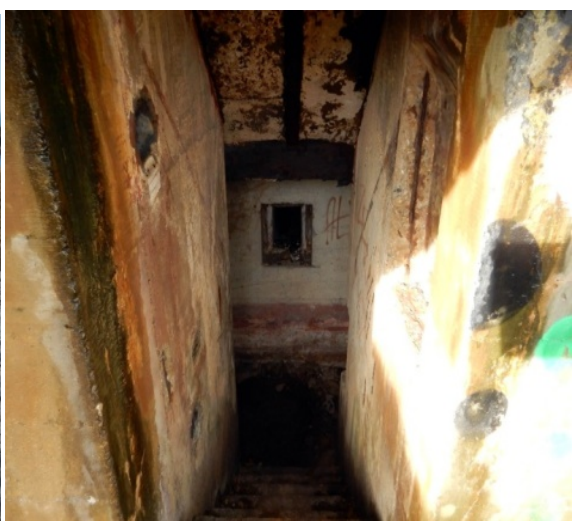

(e)

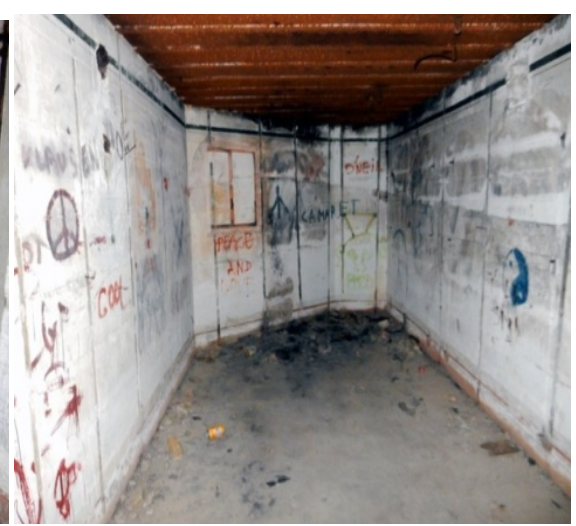

(g) 


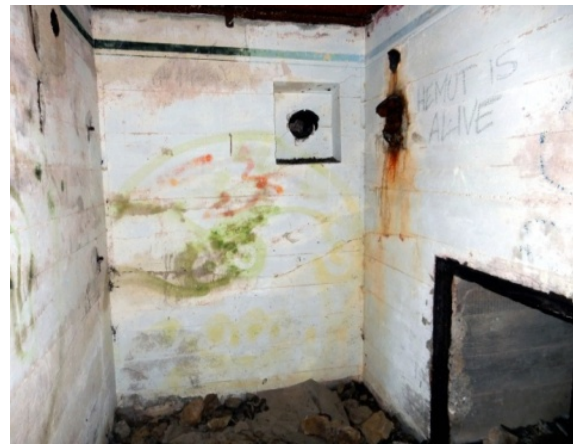

(h)

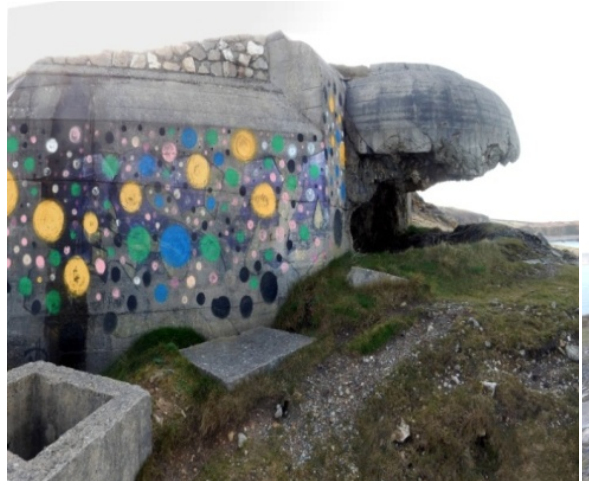

(j)

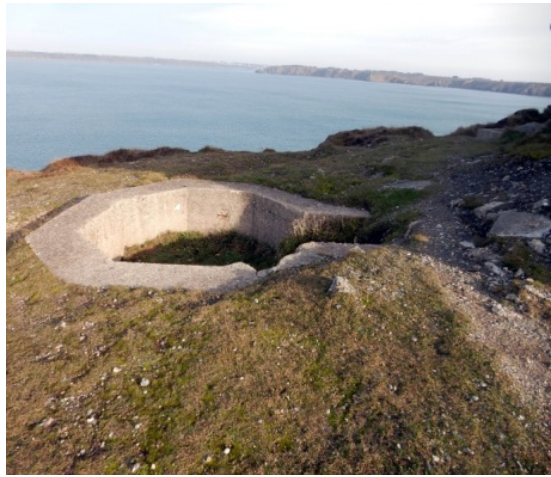

(1)

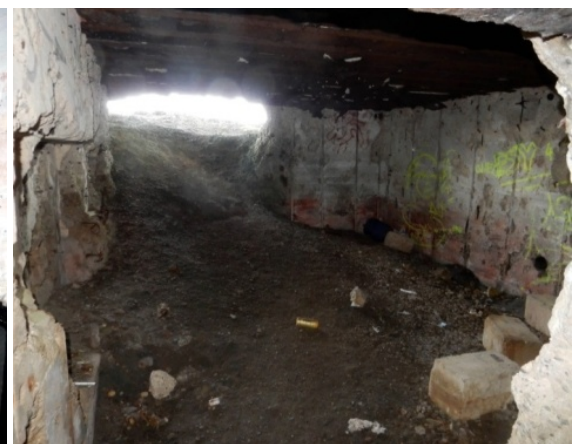

(i)

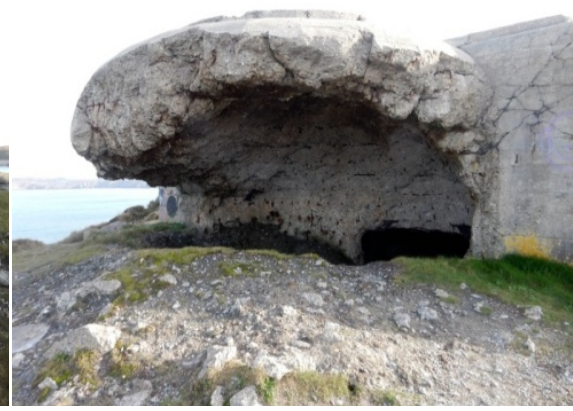

$(\mathrm{k})$

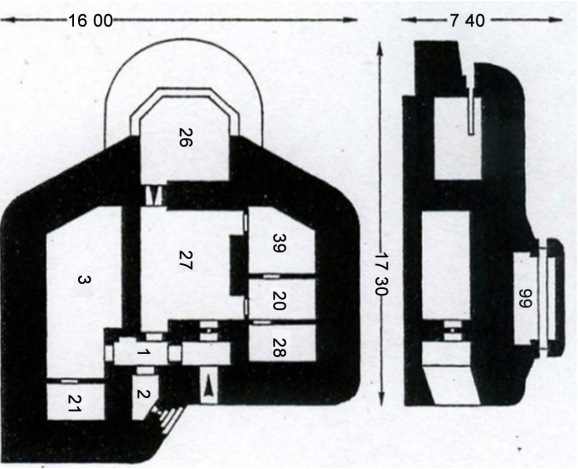

$(\mathrm{m})$

Figure 15. Coastal battery observatory and fire direction bunker (a) concrete coverage, on the right uncovered lookout post for one soldier; (b) dome coverage of the observation room; (c) rear side, on the right uncovered observation post; (d) uncovered observation post, disappeared concrete coverage; (e) entrance; (f) damaged gas lock, on the left entrance to the computing room, on the right entrance to the close fire room; $(\mathrm{g}) \mathrm{crew}$ room with painted window probably of origin and contemporary, coloured graffiti; (h) gas lock; (i) damaged computing room; ( $\mathrm{j}$ ) bunker front side; (k) damaged dome coverage of the observation room; (l) external observation post; (m) R636a standard model. 1 gas lock, 2 close fire room, 3 crew room, 20 radio room, 21 heating room, 26 observation room, 27 computing room, 28 communication room, 39 officers room, 66 rangefinder observatory (Rudi, 1998).

the interior of the bunker (Figure 15(f) \& Figure 15(i)) and the possible killing of the occupants. The observation room and the computing room were invaded by concrete debris and terrain entered from the elongated aperture of the obser- 
vation room. All the internal rooms were empty, deprived of all their original furniture, sometime decorated by contemporary, coloured graffiti. On the walls no traces of a thermal insulation system. The rooms preserved their rusted metallic ceiling and portions of aeration conduits. Outside the bunker, near the observation room, was an external, octagonal observation post for one soldier.

A square emplacement $\left(48^{\circ} 17^{\prime} 07.59^{\prime \prime} \mathrm{N}, 04^{\circ} 36^{\prime} 18.63^{\prime \prime W}\right)$ (Figure 16), about 10 $\times 10 \mathrm{~m}$. It was surrounded by $2 \mathrm{~m}$ high side walls. It presented a damaged concrete structure decorated by contemporary, coloured graffiti. The bombardment demolished part of the wall hosting the entrance and opened deep cracks on the other walls. Leaning against one of its walls, a rectangular emplacement, about 6 $\times 5 \mathrm{~m}$, presented part of the wall hosting its entrance demolished and the other walls deformed and broken in pieces.

A $2^{\text {nd }}$ open gun emplacement $\left(48^{\circ} 17^{\prime} 04.35^{\prime \prime} \mathrm{N}, 04^{\circ} 36^{\prime \prime} 17.47^{\prime \prime} \mathrm{W}\right)$ (Figure 17), about $65 \mathrm{~m}$ long and $28 \mathrm{~m}$ bright, similar to the $1^{\text {st }}$ open gun emplacement. It was an $S K$ construction formed by a concrete, circular gun emplacement, about $10 \mathrm{~m}$ diam., emerging at the terrain level, two opposed right and left $V f 51 \mathrm{a}$ ammunition bunkers and two opposed right and left H502 SK and H501 SK crew bunkers. A concrete access way ran along its sides to connect together these constructions. The gun emplacement preserved eight niches on its internal wall for storing ammunitions and materials and on the floor the trace of the fixation plates of the rail for turning the gun. No fixation plate remained in place. The gun support at the centre of the gun emplacement disappeared. Two concrete, square columns still in place at the entrance of the gun emplacement, each provided with a deep vertical groove on two opposed sides in correspondence with two other vertical grooves on the internal wall of the gun emplacement suggested that the gun emplacement could be isolated from the rest of the emplacement by inserting wooden planks in the grooves. A central rampart separated and protected the two Vf51a and the H501 SK and H502 SK, and the branches of the access way. The right and left Vf5la were crossed by the access way through their corridors. An entrance in their corridors gave access to a single ammunition room preserving on the walls the original white painting, traces of metallic joints and on the ceiling a rusty metallic cover. A rectangular wall aperture near the entrance allowed the rapid exchange of the ammunitions.

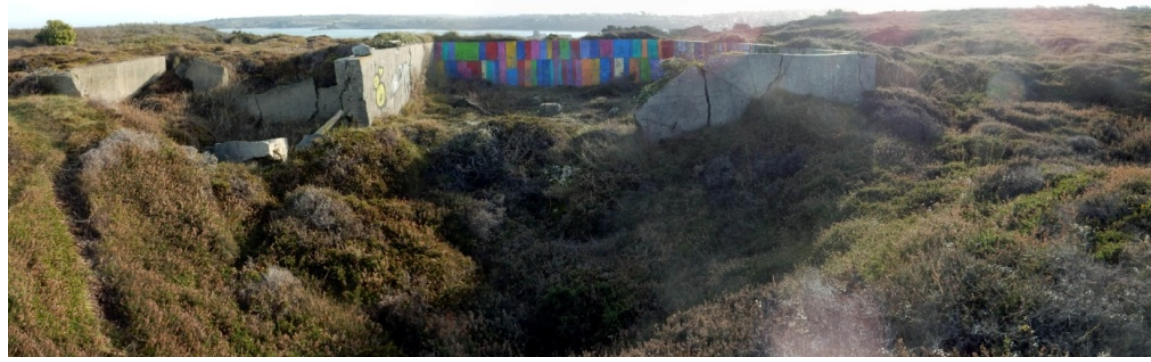

Figure 16. Square emplacement, on the left leaning rectangular emplacement. 


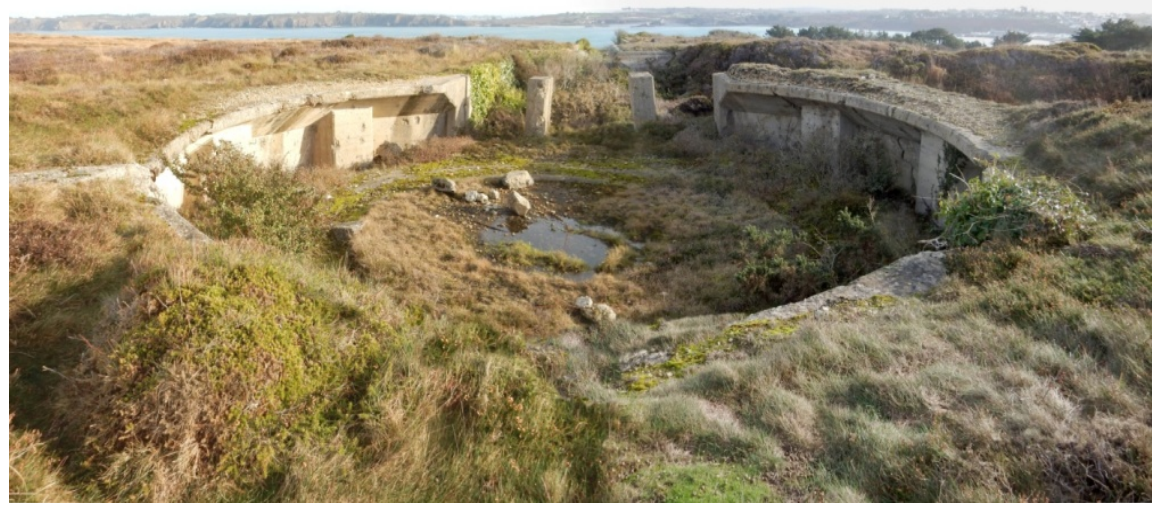

(a)

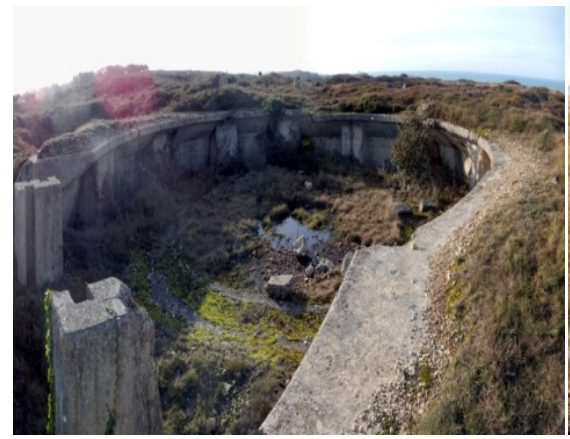

(b)

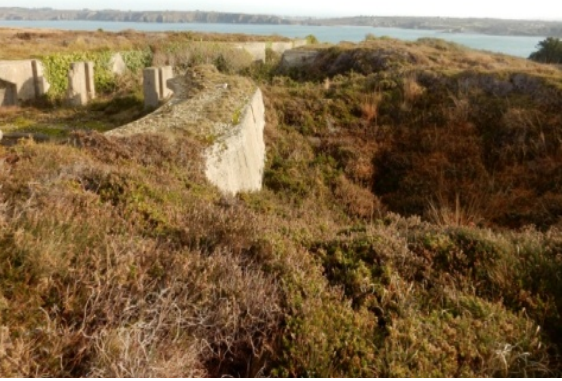

(d)

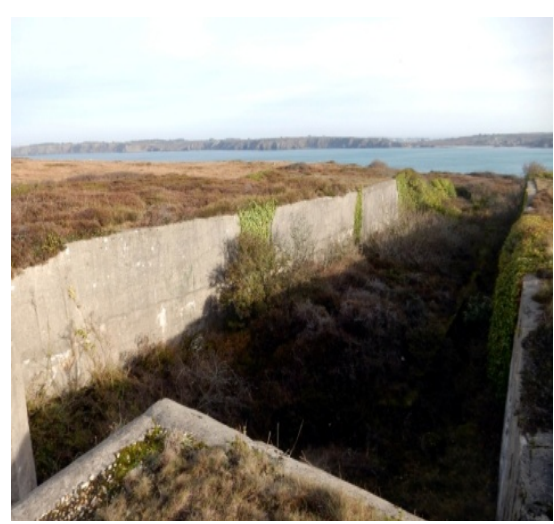

(f)

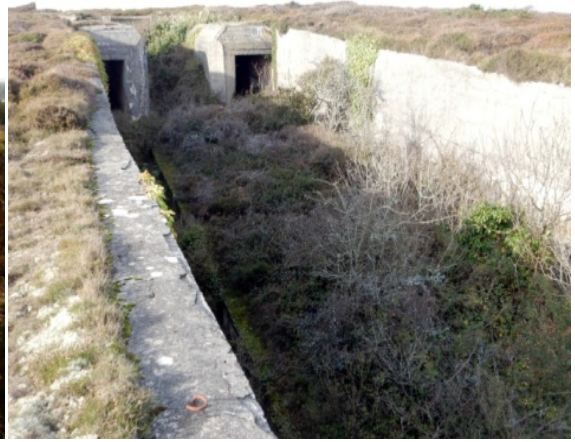

(e)

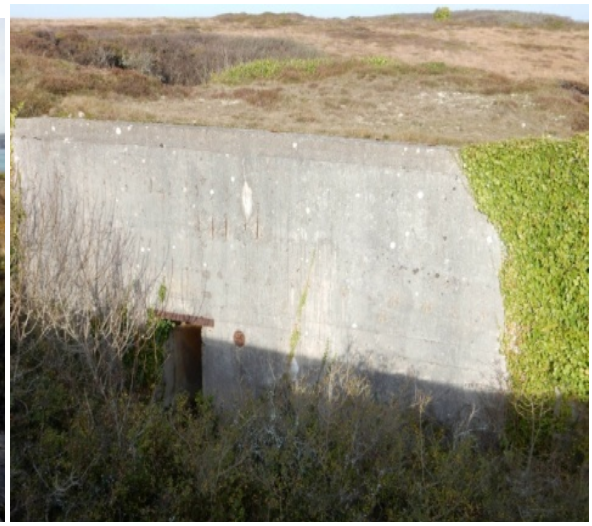

(g) 


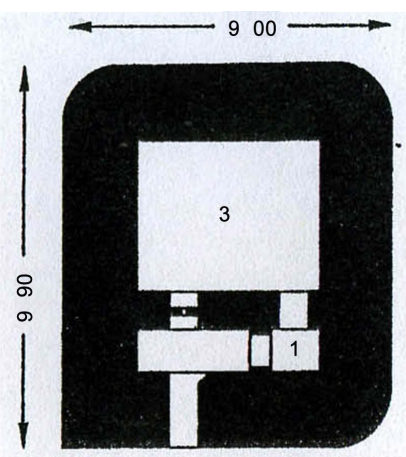

(h)

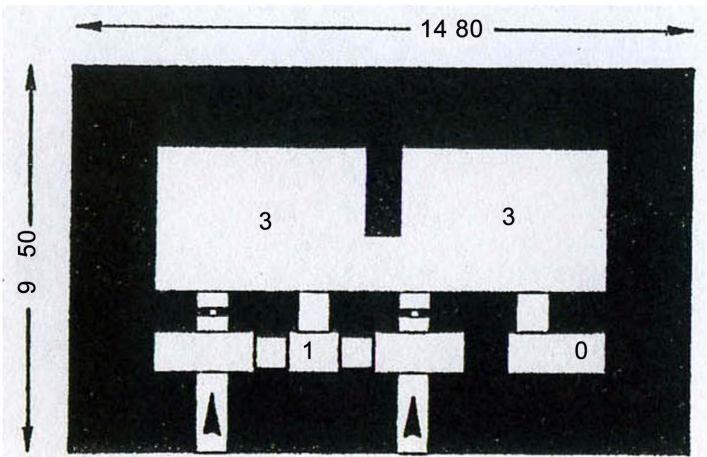

(i)

Figure 17. $2^{\text {nd }}$ open gun emplacement (a) general view; (b) circular gun emplacement with two concrete, square, columns; (c) circular gun emplacement; (d) bomb craters near the circular gun emplacement; (e) left and right Vf 51a; (f) emplacement entrance; (g) right $R 501 S K$ with a bomb crater on the upper left (h) $R 501 S K$ plan. 1 gaslock, 3 crew room (Rudi, 1998); (i) R502SK plan. 1 gaslock, 3 crew room (Rudi, 1998).

All the original room furniture disappeared. Only the walls protecting the access way branches showed impact hits of bomb splinters. The H501SK and H502SK had their entrances obstructed by the vegetation; therefore their interiors were not accessible. The $2^{\text {nd }}$ open gun emplacement substantially escaped the bombardment and presented a well preserved concrete structure decorated by contemporary, coloured graffiti.

A $3^{\text {rd }}$ open gun emplacement $\left(48^{\circ} 17^{\prime} 01.29^{\prime \prime} \mathrm{N}, 04^{\circ} 36^{\prime \prime} 22.4^{\prime \prime} \mathrm{W}\right)$ (Figure 18), of the same design of the $1^{\text {st }}$ and $2^{\text {nd }}$ open gun emplacements. It was completely destroyed by the bombardment. Its ruins were covered by terrain and thick vegetation with only some isolated emerging concrete block.

$5 \times 75$ mm C9 gun emplacements (Rapport Pinczon du Sel, 1947-1948), located between the $2^{\text {nd }}$ and $3^{\text {rd }}$ open gun emplacements, were completely destroyed. Their ruins were covered by terrain and thick vegetation with no concrete portion visible.

Three concrete, joined barracks ( $48^{\circ} 17^{\prime \prime} 06.85^{\prime \prime} \mathrm{N}, 04^{\circ} 36^{\prime \prime} 07.91^{\prime \prime} \mathrm{W}$ ) (Figure 19). They were probably of French construction judging on the accurate finishing of their walls. They hosted, respectively, personnel lodgments and a canteen. They presented well preserved concrete structures with the exception, in one of them, of a wall damaged by the bombardment, through which debris and terrain fell on the rests of a possible kitchen. All the original furniture disappeared. The search on the ground for possible mortar or gun emplacements provided no results.

A $H 622$ and a $H 638$ bunker $\left(48^{\circ} 17^{\prime} 05.45^{\prime \prime} \mathrm{N}, 04^{\circ} 36^{\prime} 12.38^{\prime \prime} \mathrm{W}\right.$ ) (Figure 20) facing each other. The $H 622$, two crew bunker, was buried in the terrain. It presented a facade without damages due to the bombardment or combats. It was accessible. On the walls, no trace of a thermal insulation system. The two crew rooms were empty, deprived by their original furniture. They preserved a rusted metallic ceiling and cot support joints on the walls. The $H 638$, small dressing bunker, was buried in the terrain and not accessible because of the vegetation that covered its facade and obstructed its entrances. Therefore, it was not possi- 


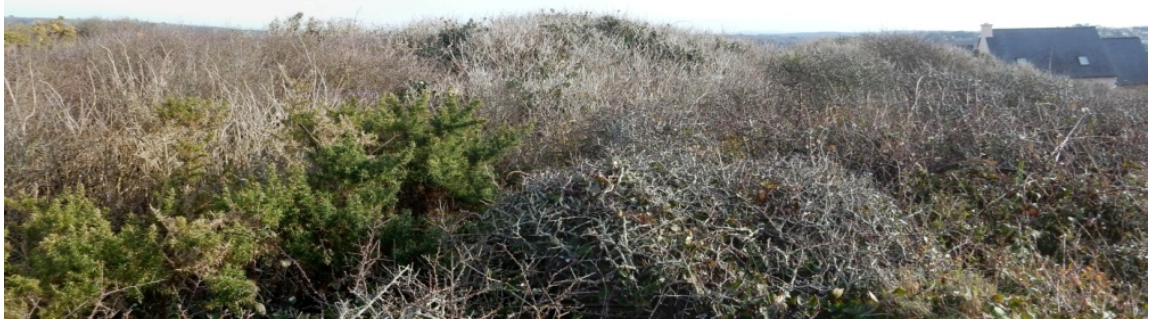

(a)

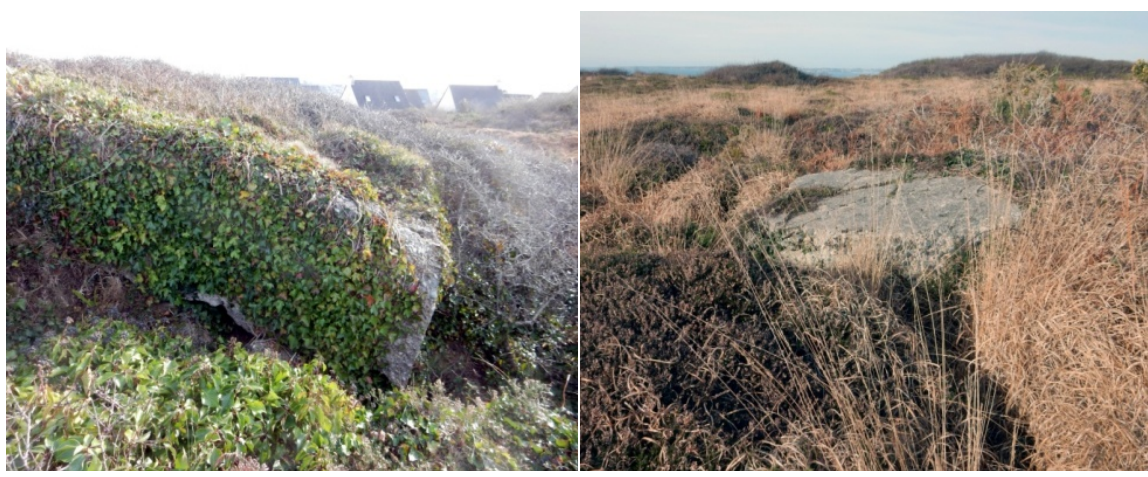

(b)

(c)

Figure 18. $3^{\text {rd }}$ open gun emplacement (a) ruins covered by the vegetation; (b) (c) emerging concrete portions.

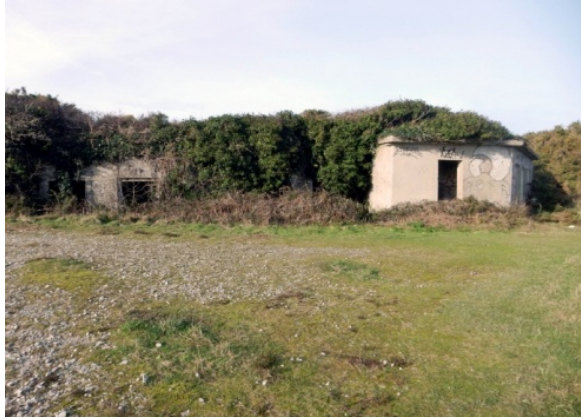

(a)

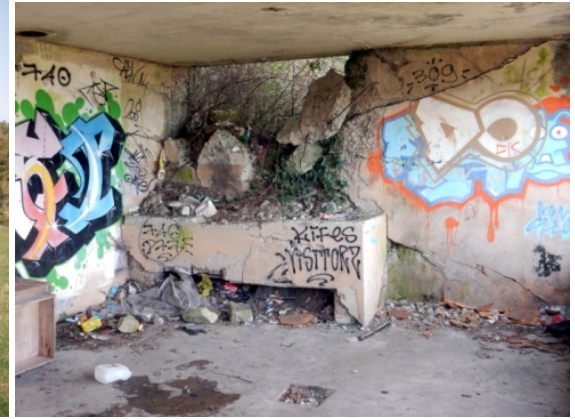

(b)

Figure 19. Three concrete barracks, probably of French construction (a) entrances of the west and east barrack; (b) east barrack interior, possible canteen.

ble to determine its preservation state. It comprised an admission room, a treatment room and two sickrooms/wards.

A H641, ammunition bunker type III (48 $\left.{ }^{\circ} 17^{\prime} 03.96^{\prime \prime} \mathrm{N}, 04^{\circ} 36^{\prime} 13.85^{\prime \prime} \mathrm{W}\right)$ (Figure 20 ), was buried in the terrain and only a small portion of it emerged. It was not accessible; therefore, it was not possible to determine its preservation state. For security reasons the shells and the cartridges of the ammunitions were stocked in separated rooms.

A $4^{\text {th }}$ open gun emplacement $\left(48^{\circ} 16^{\prime} 54.37^{\prime} \mathrm{N}, 04^{\circ} 36^{\prime \prime} 25.86^{\prime \prime} \mathrm{W}\right)$ (Figure 21 ), of the same design of the $1^{\text {st }}$ and $2^{\text {nd }}$ open gun emplacements, was completely destroyed. Its ruins were covered by terrain and thick vegetation which prevented 


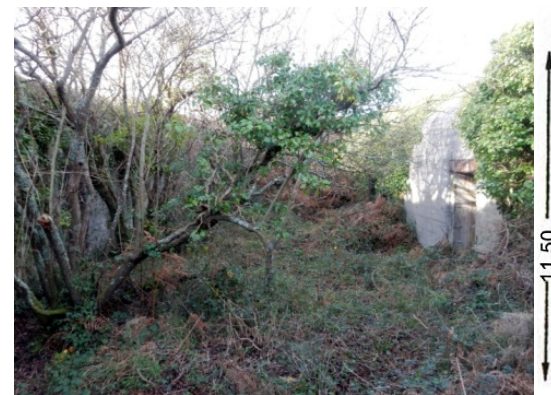

(a)

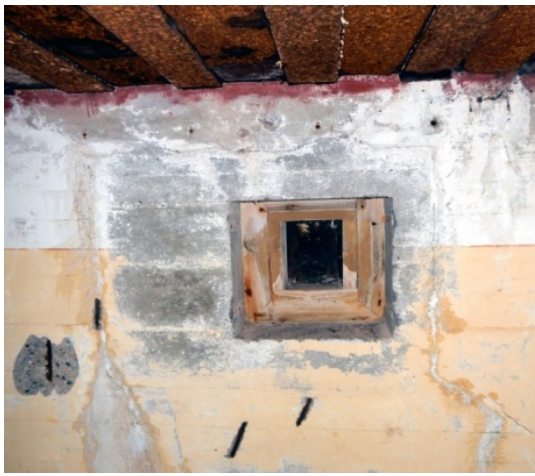

(c)

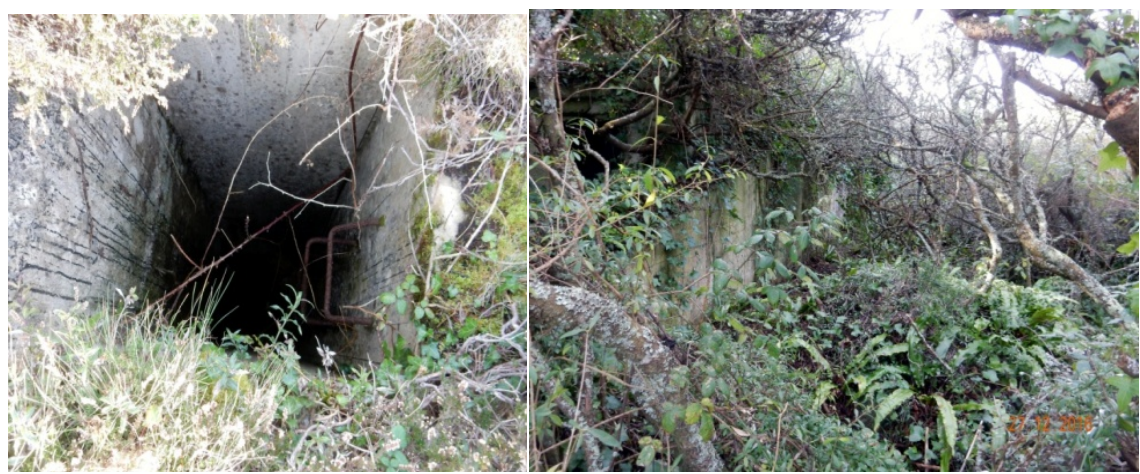

(e)

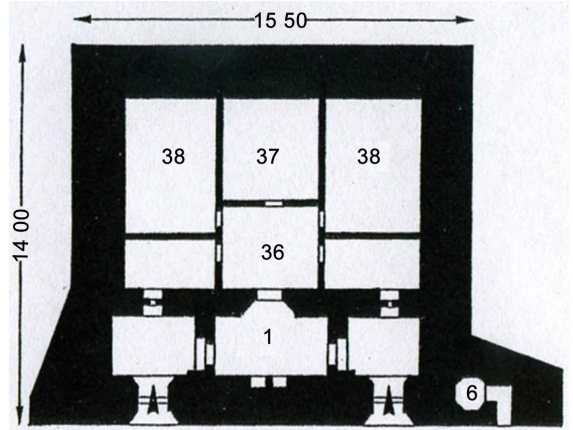

(g)

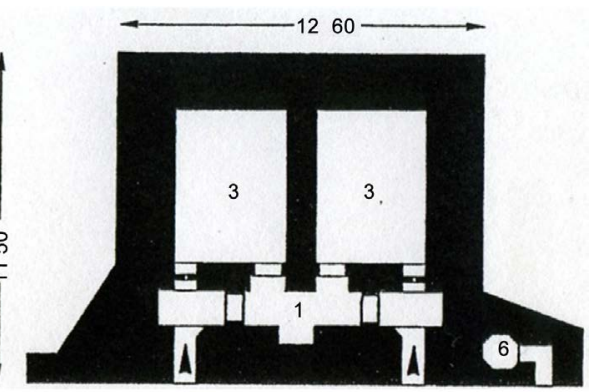

(b)

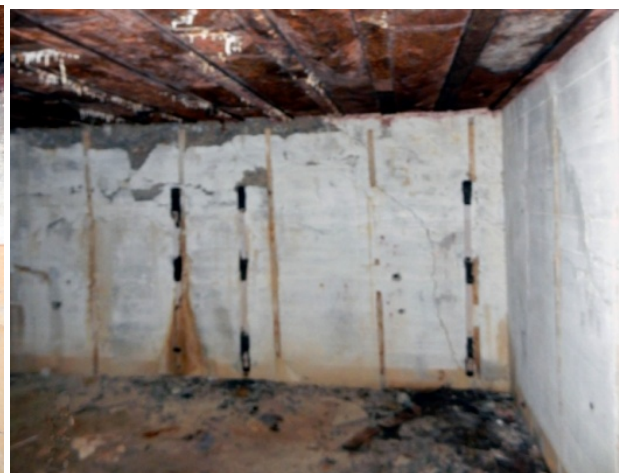

(d)

(f)

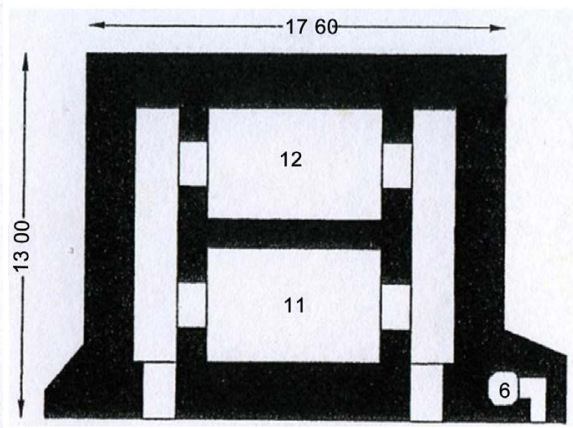

(h)

Figure 20. Facing $H 622$ and $H 638$ (a) on the left $H 638$ on the right $H 622$; (b) $H 622$ plan. 1 gas lock, 3 crew room, 6 observation post (Rudi, 1998); (c) H622 entrance; (c) H622 crew room (d) crew room, on the wall cot support joints; (e) H622 escape conduit; (f) $H 638$ covered by the vegetation; (g) $H 638$ plan. 1 gas lock, 6 observation post, 36 admission room, 37 treatment room, 38 sickroom/ward (Rudi, 1998); (h) H641 plan. 6 observation post, 11 shells room, 12 cartridge room. 


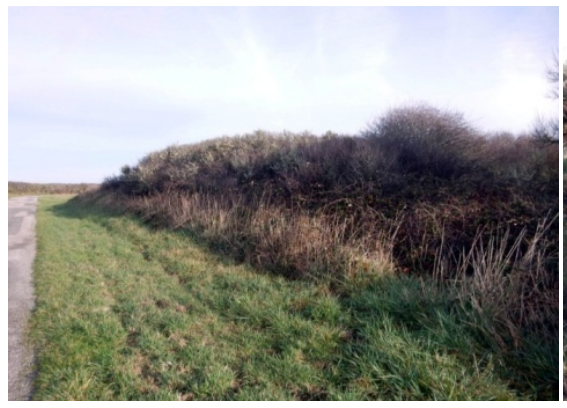

(a)

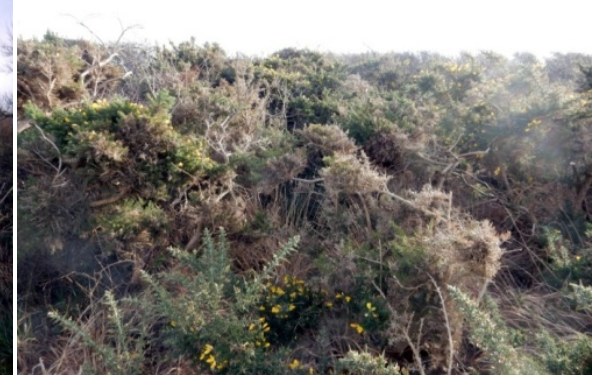

(b)

Figure 21. $4^{\text {th }}$ open gun emplacement (a)-(b) ruins covered by terrain and thick vegetation.

any recognition.

A Vf58C tobruk $\left(48^{\circ} 16^{\prime} 58.20^{\prime \prime} \mathrm{N}, 04^{\circ} 36^{\prime} 21.61^{\prime \prime} \mathrm{W}\right)$ facing the sea. It was near the $4^{\text {th }}$ open gun emplacement and presented a well preserved concrete structure without damages due to the bombardment or combats. It was a component of the H.K.B.1274 security perimeter.

The search on the ground for $6 \times 7.5 \mathrm{~m}$ mod. M32(f) AA gun emplacements, 3 $\times 2 \mathrm{~cm}$ Flak 30 gun emplacements, $2 \times 7.5 \mathrm{~cm}$ assault gun emplacements, three other Vf58C tobr ruks, $4 \times$ Maxims in FCP emplacements (Atlantikwall Co UK., 2016), wooden barracks and rests of a metallic barrier provided no result.

\section{The H.K.B.1274 Organization}

On the basis of the above description, the H.K.B.1274 organization can tentatively be traced out as follows. The Kommandantur (headquarter) of the battery and lodgements of German officers were probably located in Camaret and in the French crenelated guardhouse, the only worthy residence on the site. The guns in the $R 669 \mathrm{~s}$ of the Petit Gouin pointe were protected against air and field attacks but their shooting range was restricted to the direction of Camaret and the Camaret's Gulf for their defence or bombardment. The open gun emplacements on the Grand Gouin pointe, disposed parallel to each other in the seaward, west direction, their guns were exposed to air and field attacks but their shooting range, up to $20 \mathrm{~km}$, was unrestricted. This explains why the Mission $601 \mathrm{bom}$ bardment aimed principally to H.K.B.1274 Grand Gouin components and left aside the Petit Gouin components. The about $2 \mathrm{~m}$ wide access way in each open gun emplacement was unsuited for vehicle circulation. The ammunitions in the two $V f 51$ a were transported to the circular gun emplacement by gunners using carts. The $R 501 S K$ and $R 502 S K$ hosted respectively 6 and 12 gunners with one or more officers, which allow estimating at about 20 the number of the servants in each open gun emplacement. The platform probably hosted a radar $F M G 40 G$ (gB) Calais B (Lippmann, 2016), mounted on its own three leg support and the nearby lodgement barrack hosted instrumentation and personnel in charge of its work. The $150 \mathrm{~cm}$ parabolic searchlight was probably a type Sw 34 or 37. It was serviced by a crew of 9 members, sometime formed by Helferinnen (female helpers) (Müller, 2002). Although no other searchlight emplacement was found, 
probably this searchlight was not the only one in service at H.K.B.1274. The rangefinder device of the observatory and fire direction bunker was probably a telemeter mod. Em $4 m R(H) 34$ or $\operatorname{Em~} 4 m R(H) 36$ (Müller, 2002) hosted in the observation room. The square and the rectangular emplacements probably hosted a fuel depot. The parade and training ground was located between the $2^{\text {nd }}$ and $3^{\text {rd }}$ open gun emplacement. Woden barracks hosting services like a radio station, soldiers' lodgments, one or more kitchens canteens, cinema, douches and latrines, were probably located in front and between the open gun emplacements. Other services were certainly located in requisitioned buildings and apartments in Camaret. The faced H622 and H638 formed the H.K.B.1274 health care block. The $H 638$ received the ill and injured personnel allowing the surgeons and nurses to operate also in case of attack. The faced H662 lodged this medical personnel. The $H 641$ hosting ammunitions was disposed, for security reasons, as far as possible from the other H.K.B.1274 components. No specific power supply bunker has been identified; therefore, the battery probably received electrical power from the French public power network. The personnel in service at the battery can be roughly estimated at about $300-400$ officers and soldiers. The number of the killed among the H.K.B.1274 personnel is unknown. Probably, after the bombardment, the surviving part of ithe personnel replied for participating to the defense of the Festung (fortress) Brest.

\section{Conclusion}

Mission 601 was a successful strategic bombardment aimed to eliminate all the most important German military structures on the Crozon peninsula. A majority of the non-guided bombs used against H.K.B.1274 did not hit its most important components (Figure 2) but, however, destroyed wooden barracks, tranches and communication paths. However, a minority of them caused the partial damage of the $1^{\text {st }}$ open gun emplacement, the $R 636 a$ and the complete destruction of the $2^{\text {nd }}$ and $3^{\text {rd }}$ open gun emplacement and the $5 \times 75 \mathrm{~mm} \mathrm{C} 9$ gun emplacements. The anti-aircraft fire of H.K.B.1274, although radar assisted, as that of the other German bases around Brest (Tomezzoli, 2009), according to the bombardment report (Bohn, 1998), was not very effective in view of the relevant number of German structures damaged or destroyed and the low number of Mission 601 bombers lost or damaged. Now that HKB1274/StP C342 and its organization are known and the way is open for further studies.

\section{References}

Atlantikwall Co UK (2016). http://www.atlantikwall.co.uk/atlantikwall/fbc_c_342.php

Bohn, R. (1998). Raids Aeriens sur la Bretagne durant la seconde guerre mondiale-tome 2-les Ailes de l'Espérance, de la Souffrance et de la Liberté (1942-1944). Etudes et recherches thématiques en Finistère et en Bretagne.

Dion, M. (1996). Batteries, réduits, tours, forts, casemates. De Camaret et Roscanvel. Imprimerie de l'Iroise.

Florentin, E. (2008). Quand les alliés bombardaient la France : 1940-1945. Paris: Perrin. 
Glad Patrimoine de Bretagne (2002a). Dossier IA29001319 réalisé en 2002. http://patrimoine.region-bretagne.fr/gertrude-diffusion/dossier/corps-de-garde-crenel e-n-2-modifie-annee-1859-et-batteries-haute-4-canons-g-de-95-mm-en-1900-et-bassecr-4/6ee13bab-6186-4491-8d6d-d27effc84aaa

Glad Patrimoine de Bretagne (2002b). Dossier IA29001318 réalisé en 2002. http://patrimoine.region-bretagne.fr/gertrude-diffusion/dossier/batterie-lourde-allema nde-codee-camaret-c-342-4-canons-schneider-de-22-cm-modele-1917-en-encuvement s-2-canons-de-75-cm-sous-casemates-de-type-671/9a14f44f-fa4c-45ef-a40d-eded9be3d a84

Glad Patrimoine de Bretagne (2005). Dossier IA29001112 réalisé en 2005. http://patrimoine.region-bretagne.fr/gertrude-diffusion/dossier/batterie-de-cote-canon s-de-1647-mm-puis-batterie-lourde-allemande-code-mkb-holtzendorf-stp-re-305-4-ca nons-de-150-mm-1-maa-262/e3f8b406-21f4-435f-b1ee-2935f9ef43ac

Glad Patrimoine de Bretagne (2006a). Dossier IA29004063 réalisé en 2006. http://patrimoine.region-bretagne.fr/gertrude-diffusion/dossier/fort-du-petit-gouin/19 d28ba6-9bca-481e-a415-a1dc669144ed

Glad Patrimoine de Bretagne (2006b). Dossier IA29004061 réalisé en 2006. http://patrimoine.region-bretagne.fr/gertrude-diffusion/dossier/batteries-du-grand-etdu-petit-gouin/19138cec-3b41-4876-b09f-309aa4fe0b99

Lippmann, H. (2016). Deutsche Atlantikwall Archiv. Bretagne West mit Brest. Stand 17. http://www.atlantikwall.info/radar/france/rf_.htm\#Bretagne_West

Müller, W. (2002). Horchgeräte-Kommandogeräte und Scheinwerfer der Schweren Flak. Waffen Arsenal. Pudzun-Pallas Verlag GmbH. Wolfersheim/Berstadt.

Rapport Pinczon du Sel (1947-1948). Le Mur de l'Atlantique la Cote de la Manche et de I'Atlantique du Mont Saint-Michel a Laita. Service Historique de la Marine. Brest, Livre IV. Plan_no. (Not Indicated).

Rudi, R. (1998). Typologie du Mur de l'Atlantique. Beetsterwaag. NUGI 923.

Tomezzoli, G. (2015). The Kieswerk of Pointe Saint-Mathieu and the Atlantic Wall. Advances in Anthropology, 5, 177-182. https://doi.org/10.4236/aa.2015.54017

Tomezzoli, G., \& Dupont, Ph. (2009). Die Flakbatterien der Festung Brest. DAWA Nachrichten, Ausgabe 54, 4-43.

Tomezzoli, G., \& Marzin, Y. (2015). The Ero Vili and the Atlantic Wall. Advances in Anthropology, 5, 183-204. https://doi.org/10.4236/aa.2015.54018

Truttmann, P. (1975). Architecture militaire. In L. Calvez (Ed.), La presqu'île de Crozon (pp. 345-362). Paris: Nouvelle Librairie de France. 
Submit or recommend next manuscript to SCIRP and we will provide best service for you:

Accepting pre-submission inquiries through Email, Facebook, LinkedIn, Twitter, etc. A wide selection of journals (inclusive of 9 subjects, more than 200 journals)

Providing 24-hour high-quality service

User-friendly online submission system

Fair and swift peer-review system

Efficient typesetting and proofreading procedure

Display of the result of downloads and visits, as well as the number of cited articles Maximum dissemination of your research work

Submit your manuscript at: http://papersubmission.scirp.org/

Or contact ad@scirp.org 